\title{
Impact of monsoon shower on the hydrogeochemistry of groundwater along the lithological contact: a case study from South India
}

\author{
Devaraj Natesan ${ }^{1} \cdot$ Chidambaram Sabarathinam $^{1,2} \cdot$ Pradeep Kamaraj $^{3}$ (1) $\cdot$ Mahalakshmi Mathivanan ${ }^{4}$. \\ Muhammed Haji ${ }^{3}$. Prasanna Mohan Viswanathan ${ }^{5}$ - Thivya Chandrasekaran ${ }^{1} \cdot$ Thilagavathi Rajendran $^{1}$
}

Received: 22 October 2020 / Accepted: 15 November 2021 / Published online: 11 February 2022

(c) The Author(s) 2022

\begin{abstract}
Groundwater chemistry is mainly governed by lithological variations, space and resident time. In addition, hydrogeochemical characteristics of groundwater in the lithological contact zones are too complex. Hence, Cretaceous-Tertiary (KT) boundary from Ariyalur district, Tamilnadu, India, was selected for this study to identify the hydrogeochemistry of groundwater. This study includes 284 groundwater samples from four different seasons (pre-monsoon, post-monsoon, southwest monsoon and northeast monsoon). Groundwater samples were collected and analysed for major cations and anions, including physical parameters using standard procedures. High electrical conductivity (EC) showed the longer residence time of groundwater in hard rock region at the central and southern part of the study area. $\mathrm{Ca}^{2+}, \mathrm{Na}^{+}, \mathrm{Cl}^{-}$and $\mathrm{HCO}_{3}^{-}$are the dominant ions in all the four seasons. The seasonal composition migration was observed from $\mathrm{Na}-\mathrm{Ca}-\mathrm{Cl}-\mathrm{HCO}_{3}$ type to $\mathrm{Na}-\mathrm{Mg}-\mathrm{Cl}-\mathrm{HCO}{ }_{3}$ type, and $\mathrm{Ca}-\mathrm{HCO}_{3}$ is the predominant water type in piper plot. Interpretation of data reveals that the groundwater quality was unsuitable for domestic and irrigation purposes during pre- and southwest monsoon seasons. Rock-water interaction and dissolution of minerals are the main sources of groundwater chemistry. Agriculture activities during monsoonal seasons also play a role in controlling the hydrogeochemistry of groundwater in this region.
\end{abstract}

Keywords Hydrogeochemistry $\cdot$ Cretaceous-Tertiary $(\mathrm{KT})$ boundary $\cdot$ Lithology $\cdot$ Weathering $\cdot$ Monsoon $\cdot$ South India

\section{Introduction}

The dissolved ions in groundwater aid to recognize the major geochemical processes and help to determine the utility of water for various purposes. In regulating the contribution of the various geochemical factors during every stage shows a

Pradeep Kamaraj

pradeep.kamaraj@astu.edu.et

1 Department of Earth Sciences, Annamalai University, Chidambaram 608 002, India

2 Water Research Center, Kuwait Institute for Scientific Research, Kuwait City, Kuwait

3 Department of Applied Geology, School of Applied Natural Sciences (SoANS), Adama Science and Technology University, 1888 Adama, Ethiopia

4 School of Civil Engineering, SASTRA Deemed University, Thanjavur 613 402, India

5 Department of Applied Geology, Faculty of Engineering and Science, Curtin University, Malaysia, Miri, Sarawak, Malaysia complex process. The vast extent of the ecosphere's irrigation and agriculture relies on subsurface water. The groundwater quality of a region is determined by precipitation, geological materials, geographic, land-use geomorphology and accessibility of recharge sources. The dependence on surface water in many regions had increased rapidly due to insufficient surface water sources, non-perennial rivers, and frequent monsoon failures. In the recharge zone, hydrochemistry is affected by water chemistry and by various reactions before recharge and reactions between the groundwater and aquifer matrix ( $\mathrm{Li}$ et al. 2008). Chemical characteristics of the adjoining rocks, the qualitative and measurable characteristics of moving water bodies, and the human interaction with the subsurface aquifers govern the utility of water. The spatial variability of water chemistry results from rock-water interaction under different subsurface migration conditions (Prasanna et al. 2013).

Scientists have recognized many other factors that influence groundwater chemistry, such as the amount of pores in the aquifer, waste water penetration from shallow salt water, water level rise and seawater incursion (Araguas 2003; Carol 
et al. 2009; Senthilkumar et al. 2017; Acharya et al. 2017). Several authors have claimed that geological heterogeneities influence hydrogeochemical processes on different scales (Singh et al. 2013; Chidambaram et al. 2010; Adithya et al. 2016; Thilagavathi et al. 2017; Olofinlade et al. 2018; Devarajet al. 2018, 2020). In recent decades, groundwater quality concerns have become a major concern, and groundwater quality assessment and health risk assessment have been extensively studied around the world (Zhang et al. 2020a, b; Adimalla and Qian 2021; Adimalla et al. 2020a, b). This present study is more significant due to the difference in the adjoining lithologies, intensity of weathering, water level fluctuation, surface water-groundwater interaction, permeability and porosity of these aquifers (Archaean, Cretaceous, Tertiary and Quaternary).

Hydrogeochemical methods and the study of principle component analysis provide confidence in the degree of water-rock interactions and processes of mixing $\mathrm{Xu}$ et al. 2019a, b, c; Adimalla 2020; Adimalla et al. 2020a, b). There are few studies on the hydrogeochemical status to determine the dissolved ion concentration in the adjoining region of the study area (Mehra et al. 2016; Thivya et al. 2015, 2018; Saravanan et al. 2016; Loganathan and Ahamed 2017; Kumar et al. 2017). Irrigation water quality plots are the major keys to classify the groundwater quality (Zhang et al. 2019; Adimalla 2019). An investigation has been done to identify the hydrogeochemical characterization of groundwater (shallow aquifer) for irrigation purpose (Xu et al. 2019a, b, c).

The study about groundwater chemistry and its relation with local geology are important in groundwater management (Xu et al. 2019a, b, c). Also, Groundwater is one of the key sources of drinking water, and its use and protection as drinking water faces challenges as water tables decline (Zhang et al. 2020a, b). In order to recognize the geochemical processes accountable for the discrepancy in hydrogeochemical characters of groundwater along Cretaceous-Tertiary boundary, many studies have previously been conducted globally, though hydrogeochemical research on groundwater to ascertain the suitability for different purposes are scarce especially along the KT boundary of Trichinopoly, Tamil Nadu, India. Therefore, the current study has attempted with an intense sampling campaign representing four different seasons and adopting even distribution, to determine the water quality for various purposes, its spatial and temporal variation and to identifying chief hydrogeochemical process in the region.

\section{Study area}

The major city, Ariyalur is in the central portion of Trichinopoly district in southern Tamil Nadu, India (Fig. 1). The present study region lies between the latitude of $78^{\circ} 808^{\prime \prime} \mathrm{E}$ and $79^{\circ} 275^{\prime \prime} \mathrm{E}$, the longitudes $11^{\circ} 449^{\prime \prime} \mathrm{N}$ and $10^{\circ} 974 " \mathrm{~N}$ representing survey of India toposheets $58-\mathrm{I}-15,58-\mathrm{I}-16$, 58-M-3 and 58-M-4. The mean elevation of the area is $50 \mathrm{~m}$ above mean sea level. Physiographically the north-western portion is elevated and slopes towards the south-east with a spatial extent of $1774 \mathrm{Km}^{2}$. Temperature varies from 21 to $40{ }^{\circ} \mathrm{C}$ in January and June, respectively. Average yearly rainfall of $1096 \mathrm{~mm}$ and the highest amount of rainfall is generally recorded during NEM (i.e. $45.9 \%$ of total rainfall), followed by SWM (39.6\%), winter (2.8\%) and summer $(11.7 \%)$. The river Vellar is the major drainage flowing from the northern part and; another minor tributary is River Marudiyar moving transversely from southwest to southeast. The river Marudiyar is ephemeral and there is no flow during non-monsoon periods.

The geology the region is covered by charnockites, sandstones, migmatite gneiss and calcareous stones. The surface marine structure is characteristic of the Cauvery basin's cretaceous succession with a rich Albian-Maastrichtian era faunal sequence (Rangaraju et al. 1993). Lithological, there are 3 foremost groups classified as Ariyalur, Uttatur and Trichinopoly formations. The Ariyalur formation is the major outcrop than the other two (Sastry et al. 1972), and it outcrops on the eastern and northeastern part of the Ariyalur district. It is the most prominent fossiliferous cretaceous formations of the Cauvery basin in the south India and characterizes the Mesozoic progression. Tectonics, paleontology, stratigraphy, paleoclimate and topographic sequence have been addressed and inferred by various scholars (Banerji 1979; Sundaram and Rao 1986; Ramanathan 1979; Ramasamy and Banerji 1991; Govindan et al. 1996; Madhavaraju and Ramasamy 1999, 2001; Ayyasami 2006; Devaraj et al. 2018, 2020). The major land-cover and land-use features are agricultural terrestrial, water supplies, leftover land, scrubland and farm/plantation. The spatial coverage of these features shows, aquatic bodies (21.45\%), left over terrestrial (6.88\%), farmstead/coppice (6.29\%) and scrubland (3.1\%) representing minor portion. Agricultural land occupies $62.17 \%$ of the entire area (Devaraj et al. 2018).

Groundwater in weathered and fractured zones in semi-confined conditions depending on the interconnection between the weaker structures, and its development. In Ariyalur region, thickness of aquifer varies from 15 to 35 MBGL. The Alluvium formation is good water bearing region with a highest thickness of $37 \mathrm{~m}$ and this formation is very porous and permeable zone. Water table in the study 


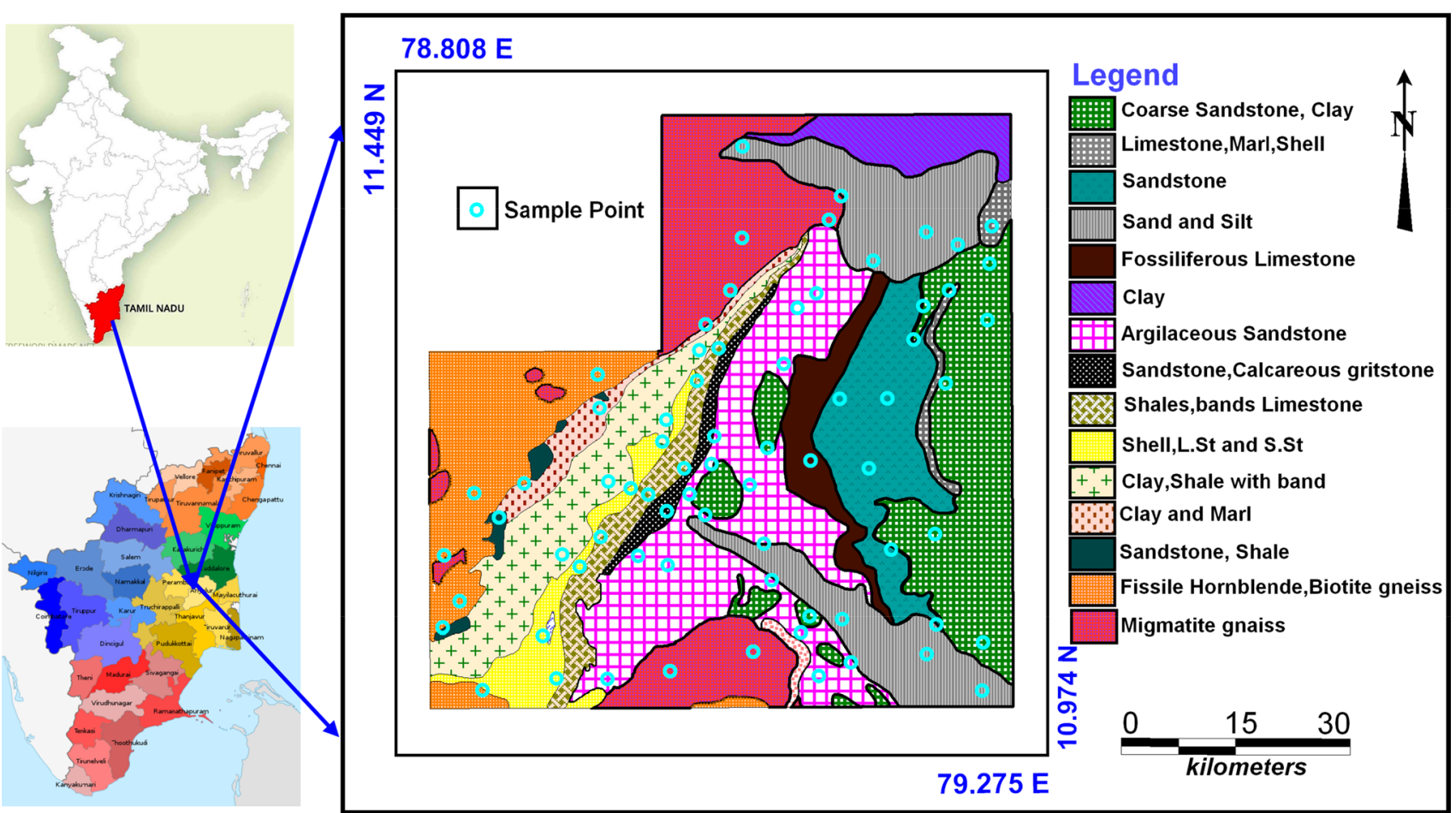

Fig. 1 Lithology map of the study area with the location of the groundwater samples

area fluctuates from 10.0 to $15.0 \mathrm{~m}$ MBGL in the hard rock aquifers.

\section{Materials and methods}

The samples representing the different litho units and land use were collected during four different season $(n=284)$ South West monsoon (SWM), Pre-monsoon (PRM), North East monsoon (NEM) and Post-monsoon (POM) (Fig. 1). Subsequently the samples were sealed and transported for analysis to the laboratory; they were stored at a temperature of $4{ }^{\circ} \mathrm{C}$ and filtered before analysis with a 0.45 -micron filter. And the samples were analysed for chemical constituents as per the standard procedure (APHA 1995). The instruments and their specifications which were used for hydrogeochemical parameters are given (Table 1). In situ analysis such as electrical conductivity (EC), $\mathrm{pH}$, total dissolved solids (TDS) and $\left(\mathrm{HCO}_{3}\right)$ bicarbonate were measured in the sampling site and cross-checked again in the laboratory. The samples obtained were analysed in the laboratory for important cations and anions. Titrimetric method was adopted for determining $\mathrm{Ca}, \mathrm{Mg}, \mathrm{HCO}_{3}$, and $\mathrm{Cl}$. $\mathrm{Na}$ and $\mathrm{K}$ were determined by flame photometer (ELICO CL 378).

Table 1 Analysing instruments and their specifications of hydrochemical parameters

\begin{tabular}{|c|c|c|c|c|}
\hline S1 No & Parameters & Chemical/Instrument used & Model/Provider & Detection limit/Accuracy and specifications \\
\hline 1 & $\mathrm{Ca}^{2+}$ & $0.02 \mathrm{~m}$ EDTA/Burette & 50,018/Riviera & GI: $0.1 \mathrm{~mL}$, Volume: $50 \mathrm{ml}$, Accuracy/Tolerance: $\pm 0.05 \mathrm{~mL}$ \\
\hline 2 & $\mathrm{Mg}^{2+}$ & $0.02 \mathrm{~m}$ EDTA/Burette & 50,018/Riviera & GI: $0.1 \mathrm{~mL}$, Volume: $50 \mathrm{ml}$, Accuracy/Tolerance: $\pm 0.05 \mathrm{~mL}$ \\
\hline 3 & $\mathrm{Cl}^{-}$ & $0.06 \mathrm{~N}$ Silver nitrate solution/Burette & 50,018/Riviera & GI: $0.1 \mathrm{~mL}$, Volume: $50 \mathrm{ml}$, Accuracy/Tolerance: $\pm 0.05 \mathrm{~mL}$ \\
\hline 4 & $\mathrm{HCO}_{3}^{-}$ & $0.02 \mathrm{~N} \mathrm{H}_{2} \mathrm{SO}_{4} /$ Burette & 50,018/Riviera & GI: $0.1 \mathrm{~mL}$, Volume: $50 \mathrm{ml}$, Accuracy/Tolerance: $\pm 0.05 \mathrm{~mL}$ \\
\hline 5 & $\mathrm{Na}^{+} ; \mathrm{K}^{+}$ & FLAME PHOTOMETER & $\begin{array}{l}\text { CL } 378 \text { /Elico Lim- } \\
\text { ited, Hyderabad, } \\
\text { India }\end{array}$ & $1-100 \mathrm{ppm}$ \\
\hline 6 & $\begin{array}{l}\mathrm{SO}_{4}{ }^{2-} \\
\mathrm{PO}_{4}{ }^{3-} \\
\mathrm{NO}_{3}{ }^{-} \\
\mathrm{H}_{4} \mathrm{SiO}_{4}\end{array}$ & UV-VIS SPECTROPHOTOMETER & DR6000/HACH, UK & $\begin{array}{l}420 \mathrm{~nm} \\
880 \mathrm{~nm}(\mathrm{OD}) \\
275 \mathrm{~nm} \\
810 \mathrm{~nm}\end{array}$ \\
\hline
\end{tabular}


Fluoride was measured by the ion electrode (Orion 94-09, 96-09). UV-double beam spectrophotometer (DR $6000, \mathrm{HACH}$ ) was used to analyse $\mathrm{NO}_{3}, \mathrm{PO}_{4}, \mathrm{SO}_{4}$ and $\mathrm{H}_{4} \mathrm{SiO}_{4}$ adopting standard techniques (APHA 1995, 1998). Each sample was analysed three times and the average was accounted. The precision of major ion analysis was calculated by using Eq. 1 (Freeze and Cherry 1979) by determining ionic balance error (IBE), and it was found that values fell within 5-10\% (Fig. 2).

$\mathrm{IBE}=[(\mathrm{TA}-\mathrm{TC}) /(\mathrm{TA}+\mathrm{TC})] \times 100$

The detailed specifications of the analytical methodology are provided in the table. Values greater than the limit of detection are diluted and measured subsequently multiplied by the dilution factor. The PCA (Factor analysis) and the Pearson correlation analysis were determined by Social Sciences Statistical Package (SPSS) version 17.0. Vertical mapper along with Map info software (Professional 8.5) was used to prepare the spatial distribution maps. The calculation on water quality indices was obtained by the programme 'WATCLAST' (Chidambaram et al. 2003). The software includes $\mathrm{Ca}^{2+}, \mathrm{Mg}^{2+}, \mathrm{K}^{+}, \mathrm{Na}^{+}, \mathrm{HCO}_{3}{ }^{-}, \mathrm{Cl}^{-}, \mathrm{SO}_{4}{ }^{2-}, \mathrm{H}_{4} \mathrm{SiO}_{4}$, $\mathrm{PO}_{4}{ }^{2-}(\mathrm{mg} / \mathrm{l})$ concentrations, and other parameters, including TDS, EC and $\mathrm{pH}$.

\section{Result and discussion}

\section{Water chemistry}

$\mathrm{pH}$

The $\mathrm{pH}$ of the water governs the solubility and thereby the geochemical equilibrium. The $\mathrm{pH}$ is a metric of the availability (activity) of hydrogen ions $\left(\mathrm{H}^{+}\right)$. The hydrogen ion is very small and can penetrate and destroy mineral structures so that dissolved components are added to the groundwater. $\mathrm{pH}$ varies from acidic to alkaline in nature, ranging from 5.54 to 8.41 (Table 2). In PRM, lowest $\mathrm{pH}$ was observed and highest during SWM.

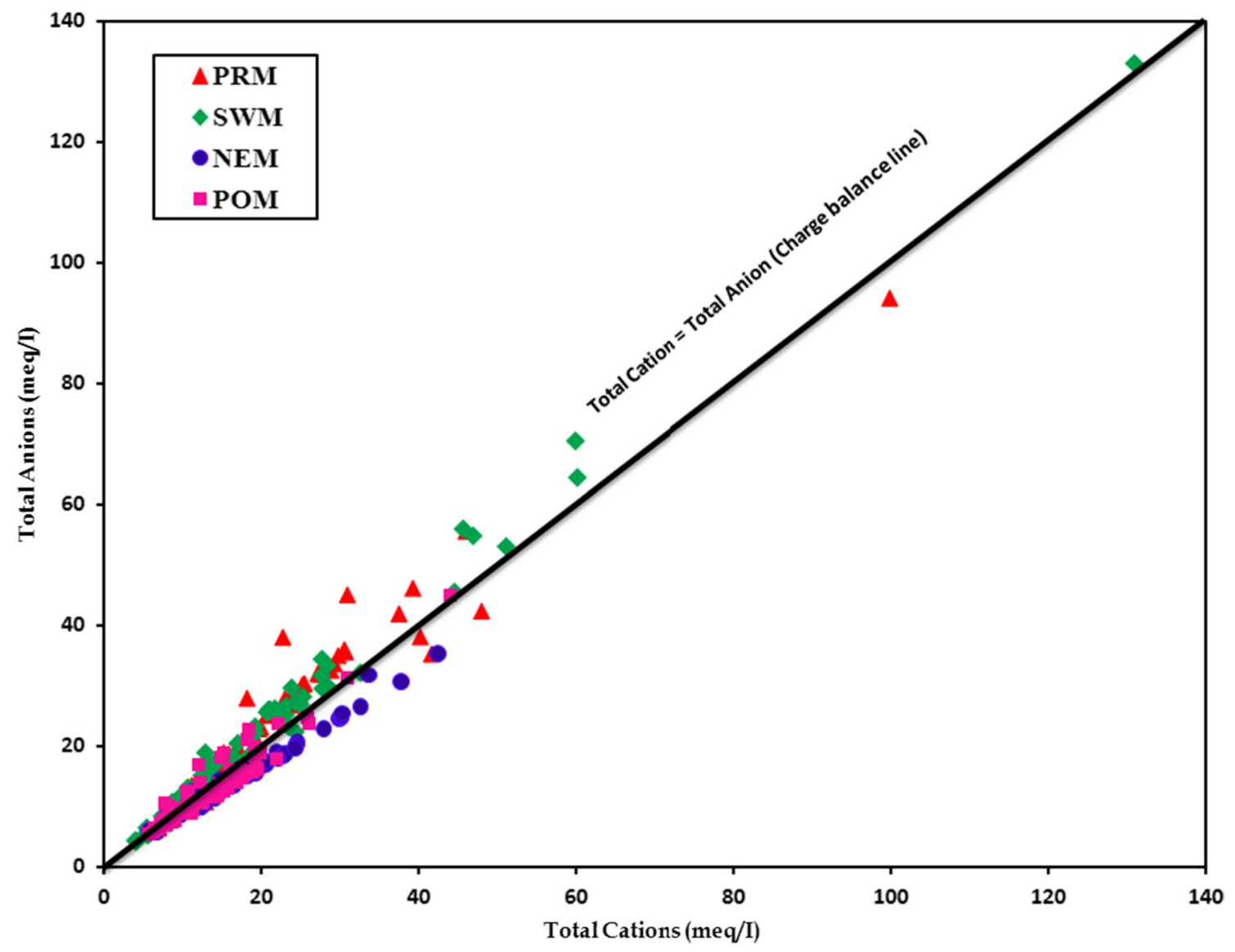

Fig. 2 Analytical values were cross checked by plotting total cations and anions for all the four seasons 
Table 2 Maximum, Minimum and Average value of the chemical constituents in groundwater representing all four seasons (All values in mg $1^{-1}$ except EC in $\mu \mathrm{s} / \mathrm{cm}^{-1}$ and $\mathrm{pH}$ )

\begin{tabular}{|c|c|c|c|c|c|c|c|c|c|c|c|c|c|}
\hline \multirow[b]{2}{*}{ Parameters } & \multicolumn{3}{|l|}{ PRM } & \multicolumn{3}{|l|}{ SWM } & \multicolumn{3}{|l|}{ NEM } & \multicolumn{3}{|l|}{ POM } & \multirow[t]{2}{*}{ WHO 2011} \\
\hline & Max & Min & Avg & Max & Min & Avg & Max & Min & Avg & Max & Min & Avg & \\
\hline $\mathrm{Ca}^{2+}$ & 304 & 16.0 & 74.1 & 272 & 8.00 & 59.5 & 328 & 28.0 & 113 & 380 & 14.0 & 113 & 75.0 \\
\hline $\mathrm{Mg}^{2+}$ & 242 & 12.0 & 42.9 & 154 & 4.8 & 38.8 & 156 & 12.0 & 55.3 & 139 & 9.6 & 55.9 & 50.0 \\
\hline $\mathrm{Na}^{+}$ & 1342 & 44.0 & 353 & 2471 & 53 & 359 & 227 & 11.8 & 96.9 & 347 & 11.0 & 72.3 & 200 \\
\hline $\mathrm{K}^{+}$ & 235 & 4.00 & 31.9 & 352 & 1.3 & 44.7 & 86.2 & 1.1 & 13.4 & 68.5 & 0.20 & 9.05 & 12.0 \\
\hline $\mathrm{F}^{-}$ & 4.00 & 0.07 & 0.67 & 0.06 & 0.01 & 0.03 & 4.0 & 0.04 & 0.68 & 4.00 & 0.04 & 0.70 & 1.50 \\
\hline $\mathrm{Cl}^{-}$ & 3172 & 53.2 & 446 & 4165 & 35.4 & 459 & 1205.3 & 53.2 & 346 & 869 & 30.45 & 209 & 250 \\
\hline $\mathrm{HCO}_{3}^{-}$ & 878 & 183 & 366 & 750 & 89 & 387 & 788 & 137 & 411 & 1135 & 130.60 & 495 & 500 \\
\hline $\mathrm{NO}_{3}^{-}$ & 475 & 3.00 & 120 & 380 & 5.00 & 94.2 & 321 & 0.13 & 25.5 & 120 & BDL & 18.8 & 45.0 \\
\hline $\mathrm{PO}_{4}{ }^{2-}$ & 0.68 & BDL & 0.05 & 1.53 & 0.01 & 0.12 & 22.9 & 0.04 & 4.07 & 0.51 & BDL & 0.03 & \\
\hline $\mathrm{SO}_{4}{ }^{2-}$ & 18.0 & 0.20 & 4.53 & 18.4 & 1.22 & 3.51 & 0.05 & $\mathrm{BDL}$ & $\mathrm{BDL}$ & 11.0 & 0.30 & 2.59 & 250 \\
\hline $\mathrm{H}_{4} \mathrm{SiO}_{4}$ & 231 & 5.20 & 120 & 242 & 18.0 & 174 & 174 & 22.0 & 102 & 170 & 26.00 & 87.7 & \\
\hline $\mathrm{pH}$ & 7.87 & 6.14 & 7.01 & 8.41 & 6.78 & 7.27 & 8.03 & 5.54 & 6.84 & 7.81 & 6.42 & 7.07 & $6.5-8.5$ \\
\hline $\mathrm{EC}$ & 13,430 & 436 & 2402 & 15,550 & 326 & 2644 & 15,400 & 668 & 3754 & 14,430 & 440 & 2657 & 500 \\
\hline TDS & 5666 & 266 & 1232 & 7810 & 200 & 1405 & 8710 & 307 & 1626 & 5983 & 248 & 1167 & 500 \\
\hline $\mathrm{Temp}^{\circ} \mathrm{C}$ & 41.1 & 27.3 & 33.6 & 33.5 & 29.1 & 31.4 & 29.5 & 29.1 & 32.5 & 38.0 & 25.9 & 30.2 & 33.0 \\
\hline
\end{tabular}

$B D L$ below detection limit

\section{Electrical conductivity (EC)}

Higher the salt content, greater the electrical current flow would be. Electrical conductance is directly related to the abundance of charged ionic compounds (Hem 1985). The study area has electrical conductivity (EC) ranging from 326 to $15,550 \mu \mathrm{s} / \mathrm{cm}$. Compared with other seasons, the highest EC value observed during SWM, it may be due to dissolution or leaching of the aquifer content, saline water influence or anthropogenic sources (Devaraj et al. 2018).

The attribute values of the specific locations were used to study the spatial variation. The general pattern of the dissolved ions in water is reflected by the spatial data of electrical conductivity. This provides us initially with first-hand data on the geochemically active regimes (Chidambaram et al. 2000; Anandhan et al. 2005; Srinivasamoorthy et al. 2004). The spatial variation of electrical conductivity with respect to samples from different seasons shows distribution of the higher values in the central part of the study area especially near the lithological contact and the hard rock region (Fig. 3).

Higher values of EC during PRM were observed along the SW and central portion of the study area. The EC ranges from 326 to $15,550 \mu \mathrm{s} / \mathrm{cm}$ during SWM and higher values were noted in the southern and NW part of the study area. The spatial distribution during NEM shows higher values in the NW region of the study area and in POM higher EC concentration was noted in the southern and SW parts. Season distribution of the values shows that the spatial coverage of EC values $>3000 \mu \mathrm{s} / \mathrm{cm}$ was observed in NEM. The higher
EC values stretch along the Vellar River during NEM due to the dissolution and infiltration of domestic sewage and landfill leachates (Saxena et al. 2003). In general, seasonal variation of EC spatial representation shows that the southern part of the study area (PRM, SWM, NEM and POM) has higher values. The categorization of the seasonal variation in samples with respect to season is observed in Table 3. Also the fluctuation of EC irrespective with seasons showed in (Fig. 4) according to Richards (1954).

The percentage of groundwater samples in each category based on this classification indicates that $36.6 \%$ of PRM samples, $80 \%$ of SWM, $26.7 \%$ of NEM and $18.3 \%$ of POM samples represent "Fresh" category. Greater percentage of samples belonging to "Brackish" category was observed during PRM, followed by SWM, NEM and POM.

\section{Total dissolved solids (TDS)}

TDS is known as the residue of filtered water samples after evaporation. Bicarbonates, sulphate, chloride, calcium, magnesium, sodium, potassium, silica and nitrate are the major dissolved solids. TDS varies between 200 and $8710 \mathrm{mg} / \mathrm{l}$ with an average of $1626 \mathrm{mg} / \mathrm{l}$ during NEM. NEM shows higher TDS followed by SWM, POM and PRM, indicating groundwater dilution during the monsoon season. Samples were categorized into four classes based on Carroll (1962). Almost 47.8\% of the SWM and POM samples represent "Fresh water" category and lesser percentage of samples represented this category during NEM (Table 4). 

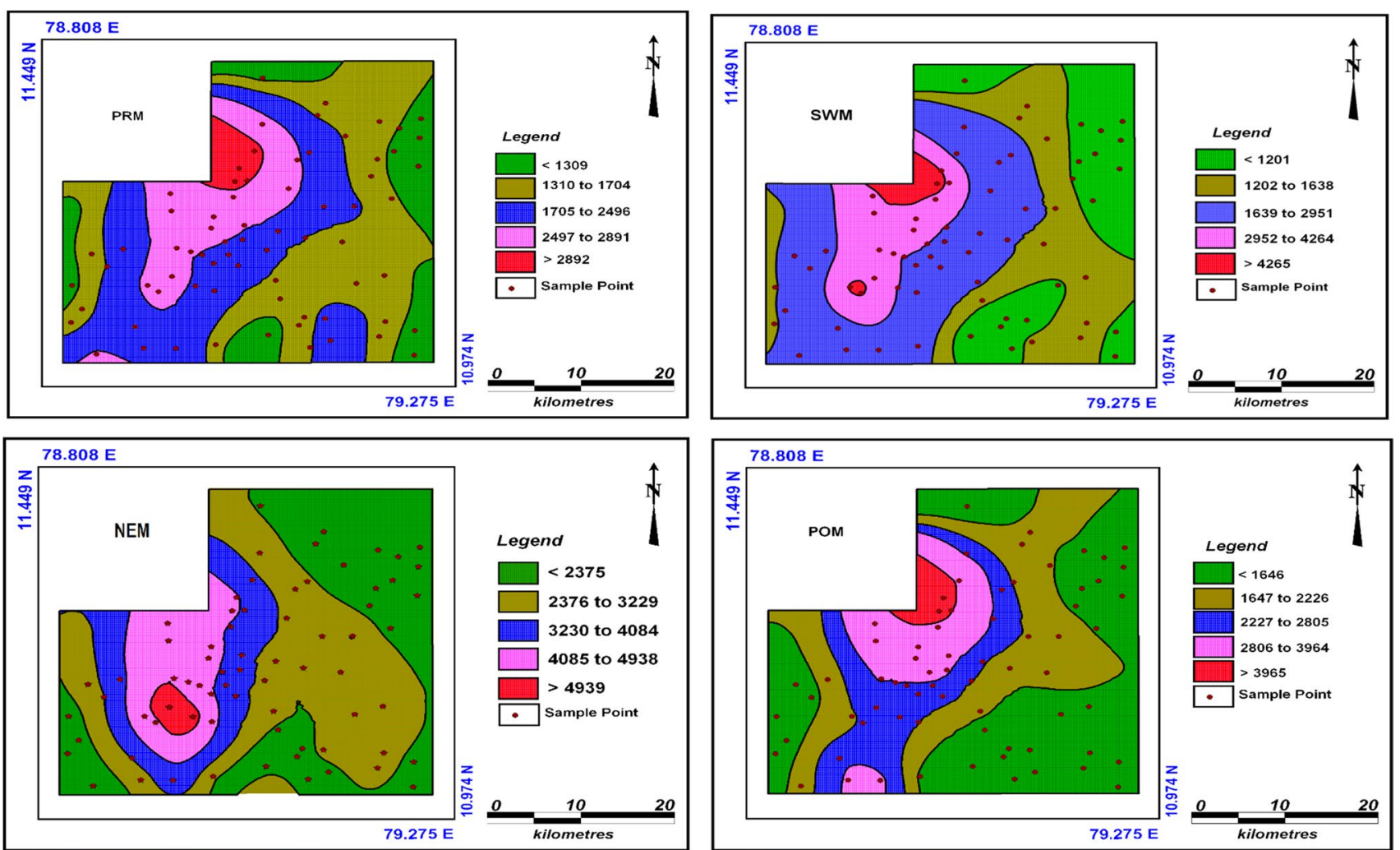

Fig. 3 The temporal variation of Electrical conductivity in the groundwater samples and their spatial distribution (all values in $\mu$ s/cm)

Table 3 Samples distributed in different categories of Electrical conductivity with respect to season

\begin{tabular}{llllll}
\hline EC Values in $\mu \mathrm{s} / \mathrm{cm}$ & PRM $(n=71)$ & SWM $(n=71)$ & NEM $(n=71)$ & POM $(n=71)$ & \\
\hline Fresh & $<1500$ & 26 & 19 & 13 & 26 \\
Brackish & $1500-3000$ & 26 & 35 & 22 & 24 \\
Saline & $>3000$ & 19 & 17 & 36 & 21 \\
\hline
\end{tabular}

Nearly $54.9 \%$ of the PRM samples fall in the "Fresh water" category.

\section{Hydrogeochemical parameters}

The average concentration of ions is observed in the order as depicted in Table 5.The calcium concentration ranges between 8 and $380 \mathrm{mg} / \mathrm{l}$ with an average of $113.35 \mathrm{mg} / \mathrm{l}$; it is observed to be higher during POM. $\mathrm{Mg}^{2+}$ varies between 4.80 and $242.40 \mathrm{mg} / \mathrm{l}$, with an average of $55.90 \mathrm{mg} / \mathrm{l}$ and highest value was observed during PRM (Chidambaram 2000). The leaching of magnesium from mafic rocks, or even hypersthene found in charnockite, is primarily the source of magnesium in groundwater. $\mathrm{Mg}$ is important for plant and animal nutrition and serves as the key source of water hardness is magnesium, along with calcium in groundwater (Matthess 1982). The sodium concentration ranged from 11 to $2471 \mathrm{mg} / \mathrm{l}$ in the samples, with an average of $358.6 \mathrm{mg} / \mathrm{l}$.
Sodium concentration is higher in SWM and lower in NEM, suggesting the contribution from the sodium feldspar weathering along with dissolution and anthropogenic sources. In most fresh water aquifers, potassium is less in groundwater due to its mobility (Hens 1985) or due to ion exchange processes (Chidambaram 2000). $\mathrm{K}^{+}$varies between 0.20 and $352 \mathrm{mg} / \mathrm{l}$ and higher concentrations were noted in SWM, averaging $44.72 \mathrm{mg} / \mathrm{l}$. Potassium is well within the prescribed limit and in most of the samples, with few anomalies due to urban landfill and fertilizer leaching, regardless of the seasons.

$\mathrm{Cl}^{-}$ranges from 30.5 to $4165 \mathrm{mg} / \mathrm{l}$ in samples, and higher concentrations were noted in SWM samples with an average of $458.85 \mathrm{mg} / \mathrm{l}$. Some locations show that the chloride in groundwater originates from both natural and anthropogenic sources, exceeding the allowable limit. The use of inorganic fertilizers, leachate from landfills, and septic tank effluent and runoff may be due to this anomalies (Freeze and Cherry 
Fig. 4 EC classification based on Richards (1954) irrespective of seasons

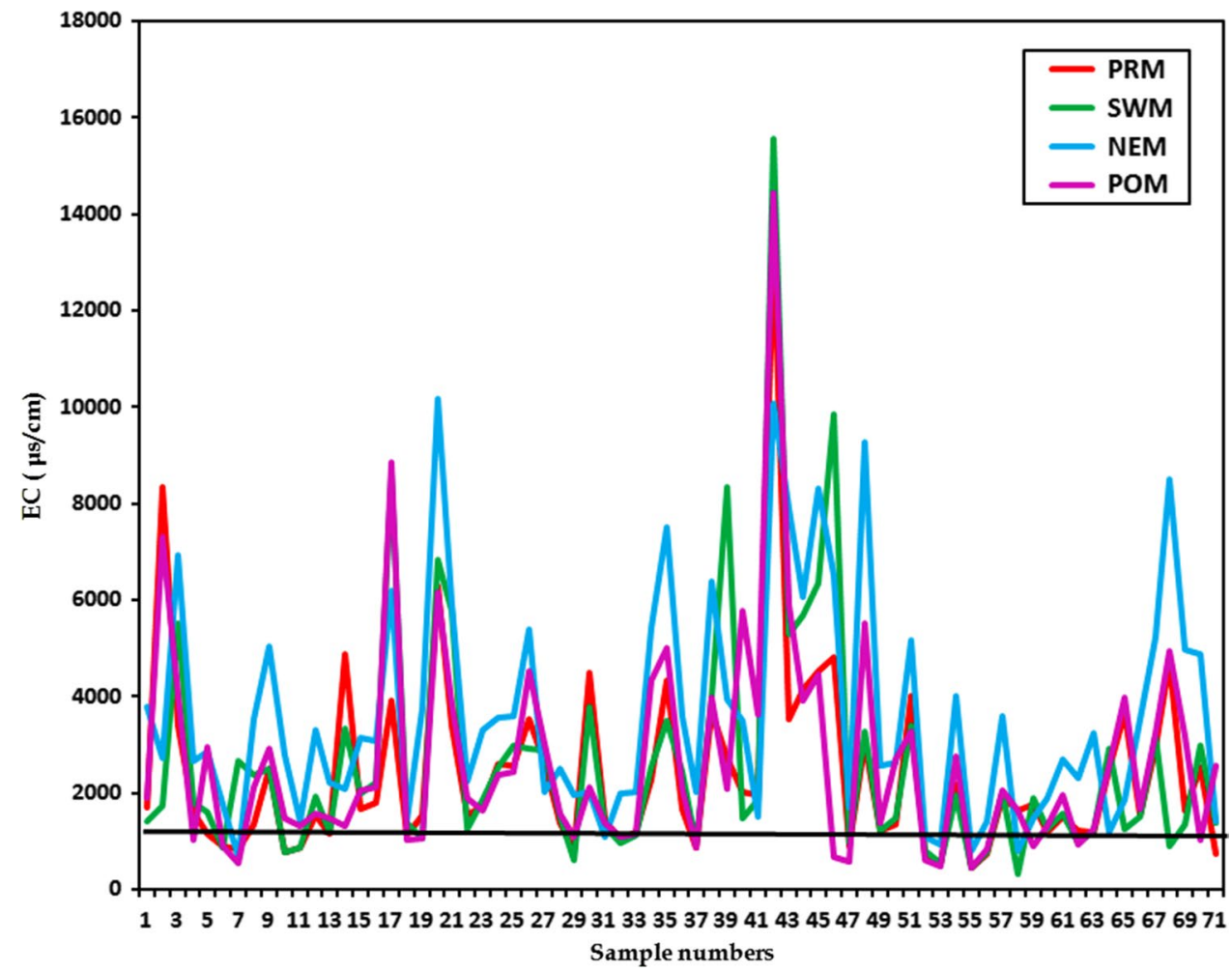

Table 4 Water quality classification based on TDS Content by Carroll (1962)

\begin{tabular}{llllll}
\hline TDS in ppm & Water quality & \multicolumn{5}{l}{ No. of samples } \\
\cline { 3 - 6 } & & PRM & SWM & NEM & POM \\
\hline $0-1000$ & Fresh water & 39 & 34 & 29 & 34 \\
$1000-10,000$ & Brackish water & 32 & 37 & 42 & 37 \\
$10,000-100,000$ & Salt Water & - & - & - & - \\
$>100,000$ & Brine & - & - & - & - \\
\hline
\end{tabular}

1979). In water, alkalinity is the indicator of its neutralization power (Chapelle et al. 1987), bicarbonate in water was attributed to $\mathrm{H}_{2} \mathrm{CO}_{3}$ dissociations. It is also produced due to the organic decomposition of atmospheric $\mathrm{CO}_{2}$ released. Bicarbonate varies between 89 and $1134.6 \mathrm{mg} / \mathrm{l}$, averaging $494.5 \mathrm{mg} / \mathrm{l}$. Average $\mathrm{HCO}_{3}{ }^{-}$values were observed to be in the following order of dominance POM, PRM, NEM and SWM, suggesting the contribution of the chemical weathering of silicate and carbonate as major source (Mondal and
Singh 2004). The nitrate accumulation in groundwater is primarily due to the infiltration of sewage and leaching of animal dung and leakage from septic tanks through the soil to groundwater (Chidambaram 2000). Nitrogen is also from the household, fertilizer or nitrogen fixing bacteria. The nitrate concentration ranged from Below Detection Limit (BDL) to as high as $475 \mathrm{mg} / \mathrm{l}$ during PRM. In the monsoon season and also by agricultural activity, they accumulated and decomposed. Sulphate is generally found in small amounts (Singh et al. 1994) in groundwater, with the maximum acceptable limit is $400 \mathrm{mg} / \mathrm{l}$ (WHO 2004). The $\mathrm{SO}_{4}{ }^{2-}$ concentration varies between BDL and $18.4 \mathrm{mg} / \mathrm{l}$ and the mean concentration is $4.5 \mathrm{mg} / \mathrm{l}$, with higher values observed during SWM. The dissolved sulphate ion contribution may also be attributable mineral dissolution, and other sources or due to bacterial fixation, fertilisers, and other anthropogenic sources (Anandhan 2005; Chidambaram et al. 2012).

The phosphate concentration ranges from BDL to $22.9 \mathrm{mg} / \mathrm{l}$ with higher concentration observed during NEM. $\mathrm{PO}_{4}{ }^{2-}$ has fluctuated without a clear pattern, regardless of space and time.
Table 5 The order of dominance of cations and anions in different seasons

\begin{tabular}{lll}
\hline Seasons & Cations & Anions \\
\hline PRM & $\mathrm{Na}^{+}>\mathrm{Ca}^{2+}>\mathrm{Mg}^{2+}>\mathrm{K}^{+}$ & $\mathrm{Cl}^{-}>\mathrm{HCO}_{3}{ }^{-}>\mathrm{NO}_{3}{ }^{-}>\mathrm{SO}_{4}{ }^{2-}>\mathrm{F}^{-}>\mathrm{PO}_{4}{ }^{3-}$ \\
SWM & $\mathrm{Na}^{+}>\mathrm{K}^{+}>\mathrm{Ca}^{2+}>\mathrm{Mg}^{2+}$ & $\mathrm{Cl}^{-}>\mathrm{HCO}_{3}{ }^{-}>\mathrm{NO}_{3}{ }^{-}>\mathrm{SO}_{4}{ }^{2-}>\mathrm{PO}_{4}{ }^{3-}>\mathrm{F}^{-}$ \\
NEM & $\mathrm{Ca}^{2+}>\mathrm{Na}^{+}>\mathrm{Mg}^{2+}>\mathrm{K}^{+}$ & $\mathrm{Cl}^{-}>\mathrm{HCO}_{3}{ }^{-}>\mathrm{NO}_{3}{ }^{-}>\mathrm{SO}_{4}{ }^{2-}>\mathrm{F}^{-}>\mathrm{PO}_{4}{ }^{3-}$ \\
POM & $\mathrm{Ca}^{2+}>\mathrm{Na}^{+}>\mathrm{Mg}^{2+}>\mathrm{K}^{+}$ & $\mathrm{HCO}_{3}{ }^{-}>\mathrm{Cl}^{-}>\mathrm{NO}_{3}{ }^{-}>\mathrm{SO}_{4}{ }^{2-}>\mathrm{F}^{-}>\mathrm{PO}_{4}{ }^{3-}$ \\
\hline
\end{tabular}


Groundwater fluoride toxicity is a result of many variables, such as fluorine-bearing mineral availability and solubility, temperature, $\mathrm{Ca}^{2+}$ and $\mathrm{HCO}_{3}{ }^{-}, \mathrm{pH}$ concentration etc (Chandra et al. 1981). Groundwater with higher fluoride is common globally, and it is governed by composition minerals and physical properties of the aquifer matrix, $\mathrm{pH}$, temperature, and the interaction with other ions (Tahaikt et al. 2008). In groundwater, F varies from 4 to $0.01 \mathrm{mg} / \mathrm{l}$, least was observed during SWM and the higher values of $\mathrm{F}^{-}$were during PRM, NEM and POM. Silica is an integral component of nearly all minerals. The silica concentration in the region varies from 5.2 to $242 \mathrm{mg} / \mathrm{l}$ with an average of $174 \mathrm{mg} / \mathrm{l}$. In SWM, higher $\mathrm{H}_{4} \mathrm{SiO}_{4}$ concentrations were observed and least during PRM, NEM and POM, suggesting dissolution from source rock.

\section{Irrigation quality}

Groundwater suitability for agriculture purpose is primarily governed by Sodium Adsorption Ratio, Sodium percent, and Residual Sodium carbonate. Apart from these parameters, total sodium concentration and EC are considered as significant (Wilcox 1955).

\section{Sodium adsorption ratio}

The appropriateness of groundwater for irrigation depends on the impact on both plants and the soil and their mineral constituents in water. The effects of salts on soils have an indirect influence on plant growth due to changes in soil composition, permeability, and aeration. The alkali hazard is stated as "Sodium Adsorption Ratio" (SAR) and is commonly utilized to determine irrigation water quality. If the water quality is high in $\mathrm{Na}^{+}$and low in $\mathrm{Ca}^{2+}$, the ion exchange sites that become saturated with $\mathrm{Na}^{+}$damage the soil structure due to the dispersion of the clay particles that decreases plant growth. The SAR is determined by using the following formula (Richard 1954).

$\left.\mathrm{SAR}=\mathrm{Na}^{+} / \sqrt{ }\left(\mathrm{Ca}^{2+}+\mathrm{Mg}^{2+}\right) / 2\right) \cdot($ Concentrations are in meq $/ L)$

In (Table 6), the classification is provided by categorizing it into excellent, good, reasonable, and bad. All samples the utility of water on crop productivity. Salinization can be caused by water with high electrical conductivity (Ghafoor et al. 1990, 1993). High salinity is unsafe water and is harmful to plants. Soils with high overall salinity levels are known as saline soils. High salt concentrations in the soil can result in a state of "physiological" drought. The salinity of water is normally determined by either TDS (total dissolved solids) or EC (electrical conductivity).

Salinity is also increases concentration of specific ions and osmotic pressure for growth and controls the plant yield (Fracois 1989). Studies of waters are categorized into four key groups (Richard 1954) based on electrical conductivity. The USSL groundwater classification for irrigation purposes (Fig. 5) was used by the United State Salinity Laboratory to acquire the irrigation water classification. This plot exhibits that majority of samples are represented in categories C3-S2, C3-S3, and C4-S4 (high salinity hazard) during the PRM and SWM and other seasonal samples of NEM, POM vary from C3-S1 and C4-S1 (low to very high salinity risk) of which the highest salinity is observed in PRM and SWM may be due to the leaching of secondary salts.

\section{Sodium percentage}

Classification of sodium percent is categorized as excellent, fine, acceptable, questionable, and unsuitable (Wilcox 1955). The content of $\mathrm{Na}$ is an important factor for evaluating appropriateness for farming purposes. The combination of sodium with $\mathrm{CO}_{3}$ contributes for the development of alkaline soils, and the combination of $\mathrm{Na}$ with $\mathrm{Cl}$ leads to the formation of saline soils. The development of these soil types hinders the plant growth (Karmegam et al. 2010; Thivya et al. 2013; Devaraj et al. 2016). An upper limit of $60 \%$ of sodium in water is permitted for agricultural purposes. The higher percentage of sodium is mainly owing to greater water residence time, dissolution of minerals, and due to the leaching of the fertilizers applied (Qiyan and Baoping 2002; SubbaRao et al. 2002). $\mathrm{Na}$ percent is classified into two categories, as safe and dangerous (Table 6). Groundwater classification for agricultural purpose using $\mathrm{Na} \%$ was determined by,

$\mathrm{Na} \%=[(\mathrm{Na}+K) /(\mathrm{Ca}+\mathrm{Mg}+\mathrm{Na}+\mathrm{K})] \times 100 .($ Concentrations are in meq $/ L)$

were found to fall into excellent categories in all seasons, with the exception of a few PRM and SWM samples.

\section{Salinity hazard}

The water salinity hazard as calculated by electric conductivity (EC) is extremely powerful parameter in determining
Similarly, in PRM, $26 \%$ of samples, $18 \%$ of samples during SWM, $98 \%$ of NEM samples and $100 \%$ of samples during POM fall into the safe category. Most of the samples from PRM and SWM are unsuitable for irrigation purposes.

The Wilcox diagram displays against $\mathrm{Na} \%$ and $\mathrm{EC}$ values (Fig. 8). The figure demonstrates approximately, $85 \%$ of the 
Table 6 Summary of Geochemical classification by WATCLAST Program for all four seasons (Chidambaram 2000)

\begin{tabular}{|c|c|c|c|c|c|}
\hline Category & Grade & $\mathrm{PRM} N=71$ & $\operatorname{SWM} N=71$ & NEM $N=71$ & $\operatorname{POM} N=71$ \\
\hline \multicolumn{6}{|l|}{ Na\% Wilcoxr (1955) } \\
\hline Excellent & $0-20$ & 0 & 0 & 14 & 28 \\
\hline Good & $20-40$ & 4 & 0 & 42 & 42 \\
\hline Permissible & $40-60$ & 15 & 13 & 14 & 1 \\
\hline Doubtful & $60-80$ & 39 & 45 & 1 & 0 \\
\hline Unsuitable & $>80$ & 13 & 13 & 0 & 0 \\
\hline \multicolumn{6}{|l|}{$\mathrm{Na} \%$} \\
\hline Safe & $<60$ & 19 & 13 & 70 & 71 \\
\hline Unsafe & $>60$ & 52 & 58 & 1 & 0 \\
\hline S.A.R. Richards (1954) & & & & & \\
\hline Excellent & $0-10$ & 52 & 51 & 71 & 71 \\
\hline Good & $10-18$ & 16 & 15 & 0 & 0 \\
\hline Fair & $18-26$ & 3 & 3 & 0 & 0 \\
\hline Poor & $>26$ & 0 & 2 & 0 & 0 \\
\hline R.S.C. Richards(1954) & & & & & \\
\hline Good & $<1.25$ & 51 & 36 & 68 & 63 \\
\hline Medium & $1.25-2.5$ & 9 & 10 & 3 & 4 \\
\hline $\mathrm{Bad}$ & $>2.5$ & 11 & 25 & 0 & 4 \\
\hline EC Wilcox (1955) & & & & & \\
\hline Excellent & $<250$ & 0 & 0 & 0 & 0 \\
\hline Good & $250-750$ & 23 & 4 & 17 & 6 \\
\hline Permissible & $750-2250$ & 43 & 39 & 40 & 35 \\
\hline Doubtful & $2250-5000$ & 4 & 18 & 10 & 22 \\
\hline Unsuitable & $>5000$ & 1 & 10 & 3 & 7 \\
\hline Category & Grade & $\mathrm{PRM} N=71$ & SWM $N=71$ & $\operatorname{NEM} N=71$ & $\operatorname{POM} N=71$ \\
\hline USGS Hardness & & & & & \\
\hline Soft & $<75$ & 0 & 1 & 0 & 0 \\
\hline Slightly Hard & $75-150$ & 5 & 14 & 0 & 0 \\
\hline Moderately Hard & $150-300$ & 31 & 32 & 10 & 10 \\
\hline Very Hard & $>300$ & 203 & 256 & 229 & 229 \\
\hline IBE Schoeller (1965) & & & & & \\
\hline$(\mathrm{Na}+\mathrm{k})$ rock- $>\mathrm{Ca} / \mathrm{Mg}$ g.w & & 60 & 61 & 5 & 14 \\
\hline$(\mathrm{Na}+\mathrm{k})$ g.w.- $>\mathrm{Ca} / \mathrm{Mg}$ rock & & 11 & 10 & 66 & 57 \\
\hline Schoeller Classification (19 & & & & & \\
\hline Type I & & 71 & 71 & 71 & 71 \\
\hline Type II & & 0 & 0 & 0 & 0 \\
\hline Type III & & 0 & 0 & 0 & 0 \\
\hline Type IV & & 0 & 0 & 0 & 0 \\
\hline Corrosivity Ratio (1990) & & & & & \\
\hline Safe & $<1$ & 43 & 37 & 33 & 14 \\
\hline Unsafe & $>1$ & 28 & 34 & 38 & 57 \\
\hline Chloride Classification & & & & & \\
\hline Extremely fresh & & & & & \\
\hline Very fresh & & 0 & 0 & 0 & 0 \\
\hline Fresh & & 0 & 0 & 0 & 0 \\
\hline Fresh Brackish & & 8 & 18 & 15 & 34 \\
\hline Brackish & & 24 & 17 & 22 & 22 \\
\hline Brackish-salt & & 33 & 29 & 29 & 15 \\
\hline Salt & & 6 & 7 & 2 & 0 \\
\hline Hyperhaline & & 0 & 0 & 0 & 0 \\
\hline
\end{tabular}


Table 6 (continued)

\begin{tabular}{|c|c|c|c|c|}
\hline Category & $\mathrm{PRM} \mathrm{N}=71$ & SWM N=71 & $\mathrm{NEM} \mathrm{N}=71$ & $\mathrm{POM} N=71$ \\
\hline \multicolumn{5}{|c|}{ TDS Classification(USSL,1954) } \\
\hline$<200$ & 0 & 0 & 0 & 0 \\
\hline $200-500$ & 1 & 6 & 0 & 10 \\
\hline $500-1500$ & 25 & 42 & 13 & 43 \\
\hline $1500-3000$ & 26 & 15 & 22 & 16 \\
\hline \multicolumn{5}{|l|}{ CationFacies } \\
\hline $\mathrm{Ca}-\mathrm{Mg}$ Facies & 0 & 0 & 16 & 27 \\
\hline $\mathrm{Ca}-\mathrm{Na}$ Facies & 67 & 65 & 55 & 44 \\
\hline $\mathrm{Na}-\mathrm{CaFacies}$ & 4 & 6 & 0 & 0 \\
\hline Na Facies & 0 & 0 & 0 & 0 \\
\hline \multicolumn{5}{|l|}{ Anion facies } \\
\hline HCO3 Facies & 0 & 0 & 0 & 0 \\
\hline HCO3-Cl-SO4 Facies & 0 & 0 & 0 & 0 \\
\hline Cl-SO4-HCO3 Facies & 60 & 58 & 66 & 71 \\
\hline Cl-Facies & 11 & 13 & 5 & 0 \\
\hline \multicolumn{5}{|c|}{ Hardness Classification (Handa 1964) } \\
\hline \multicolumn{5}{|c|}{ Permanent Hardness $(\mathrm{NCH})$} \\
\hline A1 & 3 & 0 & 17 & 34 \\
\hline A2 & 3 & 1 & 37 & 18 \\
\hline A3 & 33 & 26 & 2 & 0 \\
\hline \multicolumn{5}{|c|}{ Temporary Hardness (CH) } \\
\hline B2 & 15 & 28 & 1 & 0 \\
\hline B2 & 15 & 28 & 1 & 0 \\
\hline B3 & 16 & 15 & 0 & 0 \\
\hline
\end{tabular}

Fig. 5 USSL diagram representing irrigation quality of groundwater samples for the four seasons

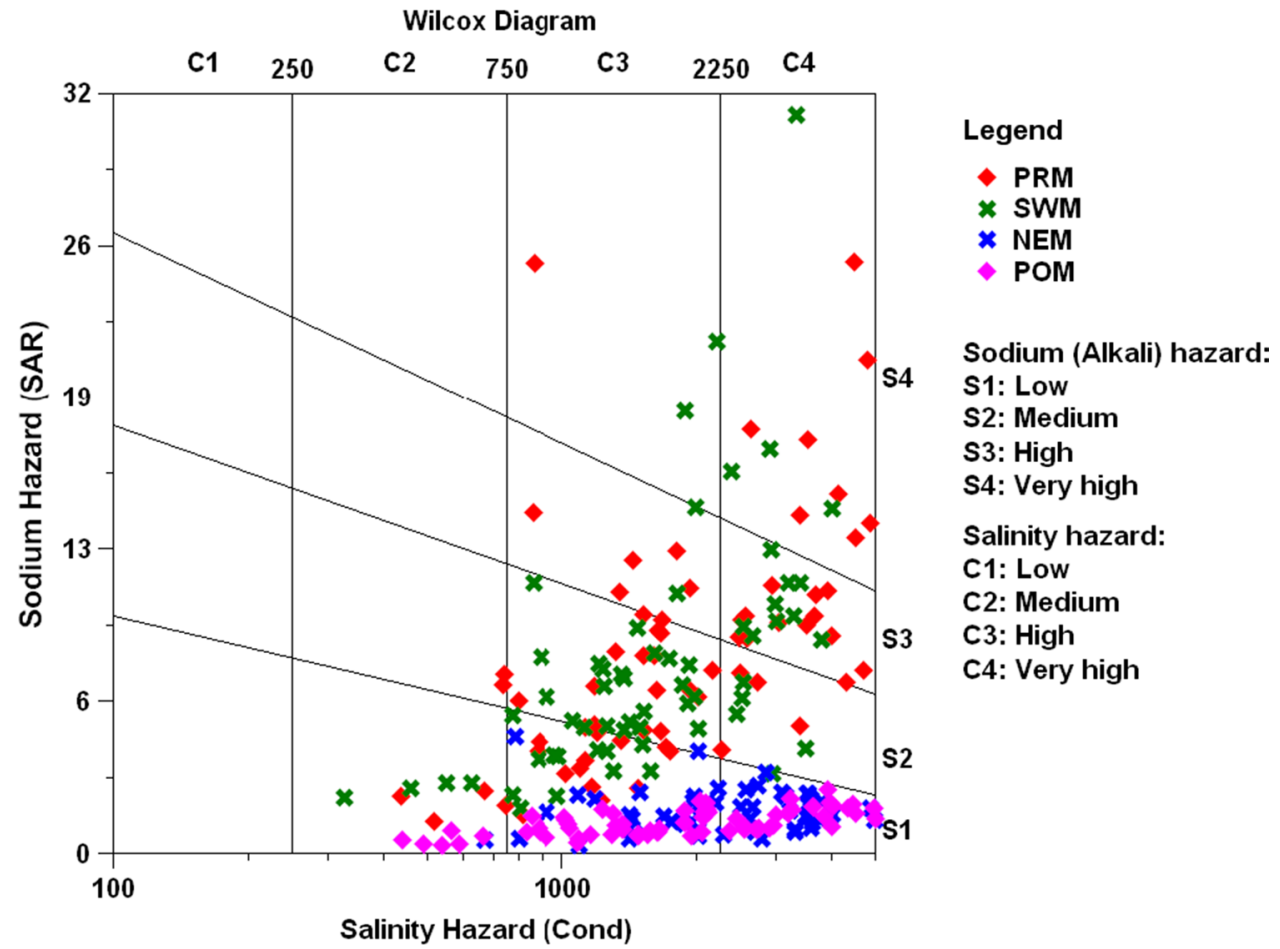


groundwater samples are fall into excellent to good condition, $13 \%$ of the samples fall in the permissible to doubtful condition and $2 \%$ sample belongs to the good to a permissible field.

\section{Residual sodium carbonate (RSC)}

The excess carbonate will increase the precipitation tendency of $\mathrm{CaCO}_{3}$ in the sediments, which in turn will enhance

\section{Permeability index}

A water quality infiltration problem is reported when the penetration rate for the water decreases or even after the rainfall event water stays on the soil surface for a long period of time or infiltrates too slowly to provide the crop with enough water to sustain appropriate yields. Doneen (1948) derived the permeability index (PI) parameter of determining the suitability of water for irrigation as;

$\mathrm{PI}=\left[\left\{\mathrm{Na}+\left(\sqrt{ } \mathrm{HCO}_{3}\right)\right\} /(\mathrm{Ca}+\mathrm{Mg}+\mathrm{Na})\right] \times 100 .($ Concentrations are in meq $/ L)$

the $\mathrm{Na}$ concentration in water. In addition, it is possible that $\mathrm{Na}$ will be controlled during the ion dispersion process (Emerson and Bakker 1973). RSC also impacts the absorption nutrients by the plants (Kanwar and Chaudhry 1968). Thus, the alkaline land affects the utility of groundwater for irrigation.
The Permeability Index is an important factor for evaluating the soil-related quality of irrigation water for agricultural improvement (Thilagavathi et al. 2012; Adimalla and Venkatayogi 2018). If there is a micronutrient deficiency, it can lead to an increase in toxicity associated with $\mathrm{HCO}_{3}$. The Permeability Index of the groundwater sample calculates the cumulative

Residual Sodium Carbonate $=\left(\mathrm{CO}_{3}+\mathrm{HCO}_{3}\right)-(\mathrm{Ca}+\mathrm{Mg}) .($ Concentrations are in meq $/ L)$

RSC is categorized into three groups as "Good", "Medium", and "Poor", according to Richard (1954) (Table 6). $72 \%$ of samples fall in good category during PRM, $12 \%$ fall in medium and $15 \%$ fall in the poor category. In SWM, $51 \%$ of samples fall into good and $14 \%$ fall in poor categories. During NEM, 35\% of samples represent "good", $95 \%$ in "medium" and 4 percent of samples reflect a "poor" class. In POM, $89 \%$ of samples fall in "good category", $6 \%$ in "moderate" and $6 \%$ of samples are poor.

\section{Corrosivity ratio}

Water is being brought through metal pipelines for many purposes to the study area. The appropriateness of the groundwater for transport is based on the sample's corrosive nature. The value of $<1$ is safe and the value of $>1$ is dangerous. The $\mathrm{CR}$ is calculated by the following formula; intensity of the total cation content of $\mathrm{Na}$ and $\mathrm{HCO}_{3}$. Permeability Index values were plotted along with sodium adsorption ratio. Most samples irrespective of the seasons represent Class I (Figs. 6, 7 and 8) representing the permissible category, with only a few samples PRM, SWM and NEM and SWM in Class II and one SWM sample representing Class III, (poor category). It is important to note that there is a linear distribution in Class I between SAR and PI and it increases in Class II and III.

\section{Chloro-alkaline indices}

The "Chloro-Alkaline Indices" (Schoeller 1977) unravels the geochemical interaction between aquifer matrix and the groundwater media during residence time in the aquifer and along the groundwater flow.

$\mathrm{CA} \mathrm{I}=\mathrm{Cl}-(\mathrm{Na}+\mathrm{K}) / \mathrm{Cl}$. (Concentrations are in meq $/ L)$

and

$\mathrm{CR}=\left\{(\mathrm{Cl} / 35.5)+\left(\mathrm{SO}_{4} / 96\right)\right\} / 2\left(\mathrm{HCO}_{3}\right) * 100 .($ Concentrations are in $\mathrm{mg} / L)$

CA II $=(\mathrm{Na}+\mathrm{K}) /\left(\mathrm{SO}_{4}+\mathrm{HCO}_{3}+\mathrm{CO}_{3}+\mathrm{NO}_{3}\right) \cdot($ Concentrations are in meq/L)

$61 \%$ of samples during PRM, 52\% of samples of SWM, $46 \%$ of samples of NEM, and $20 \%$ of samples in POM are in safe category.
Chloro-Alkaline indices are either be 'positive' or 'negative'; it exhibits an exchange of $\mathrm{Mg}+\mathrm{Ca}$ in water to that of $\mathrm{Na}+\mathrm{K}$ in aquifer matrix or the reverse of sodium / potassium from rock. 
Fig. 6 Modified Doneen's plot for determining the appropriateness of groundwater for different seasons (after Manivannan 2011)

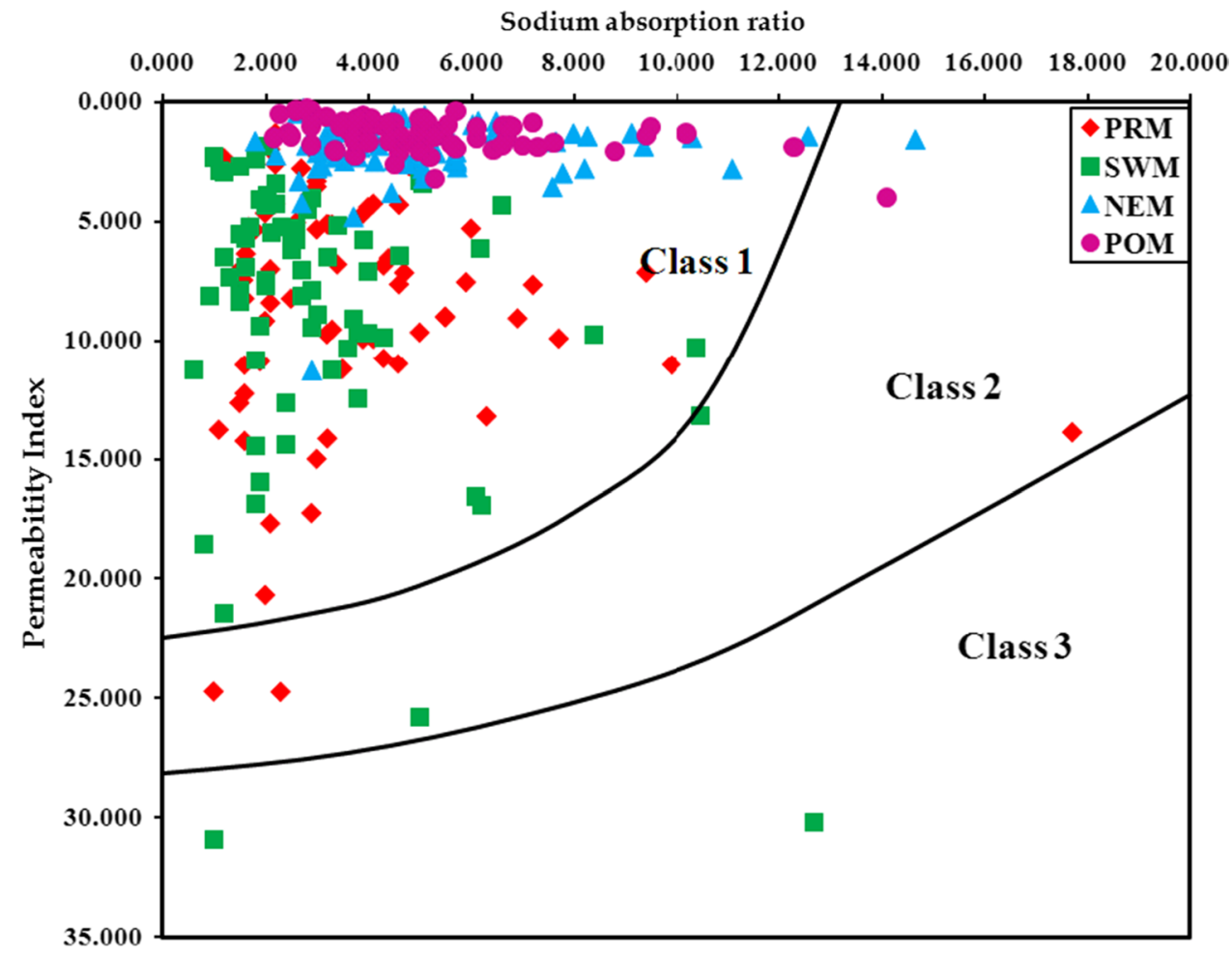

Classification of irrigation waters for soils of medium permeability

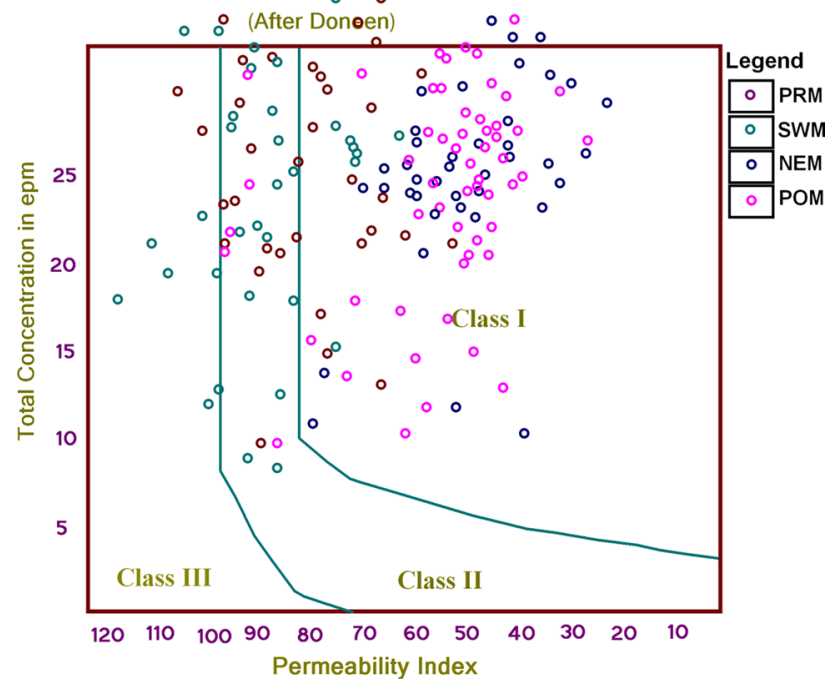

Fig. 7 Doneen's plot for determining the appropriateness of groundwater for different seasons

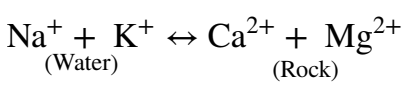

To explain the groundwater metasomatism, Schoeller (1977) suggested "Index of Base Exchange" (IBE). There are some minerals capable of adsorption and cation exchange with those in groundwater (clay minerals, glauconite, zeolite and organic substances). The exchange of cations plays a

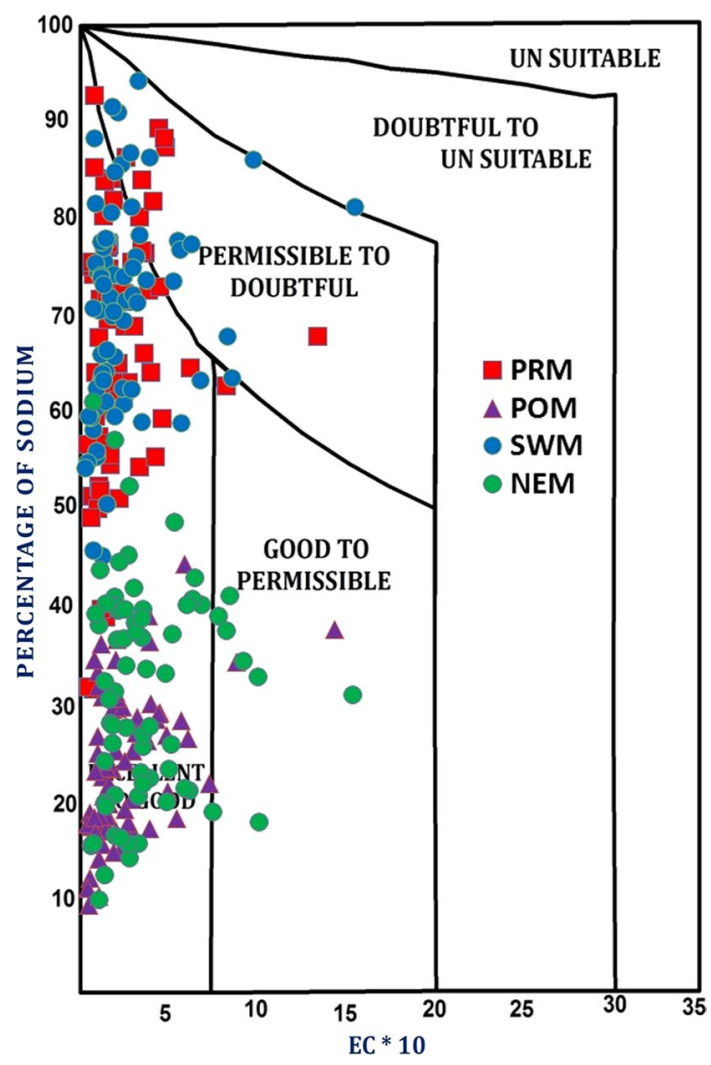

Fig. 8 Wilcox diagram representing irrigation quality of groundwater samples for the four seasons 


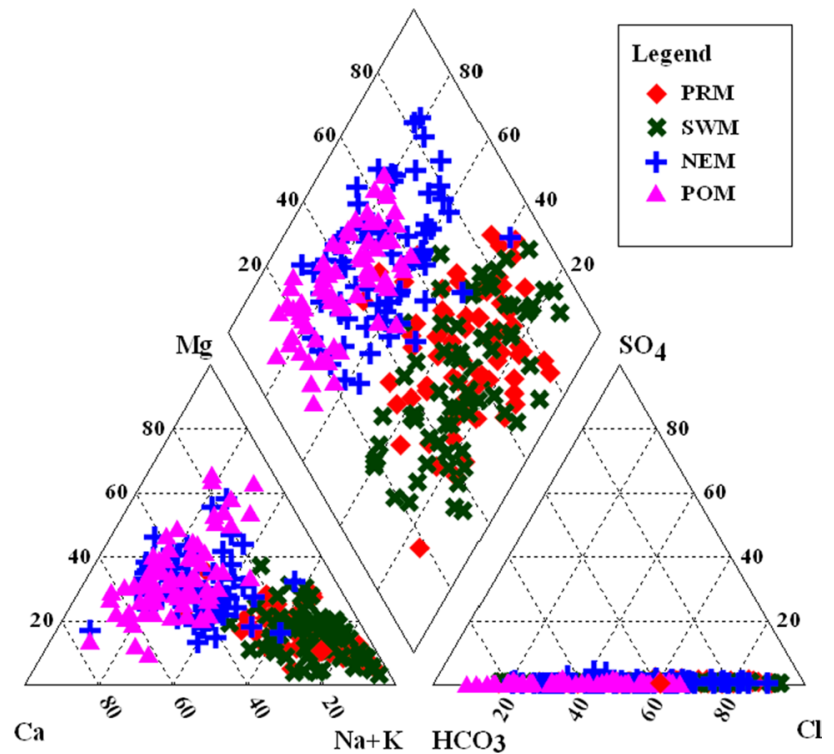

Fig. 9 Piper plot representation of samples from four different seasons

major role in the $\mathrm{Na}+\mathrm{K}$ in the groundwater. The positive ratio reflects the probability of $\mathrm{Ca}+\mathrm{Mg}$ (water) exchange to $\mathrm{Na}+\mathrm{K}$ (mineral) as $84 \%, 85 \%, 7 \%$ and $20 \%$ of samples are represent this process during PRM, SWM, NEM and POM respectively.

\section{Piper plot}

According to the seasonal variation, the water type of the sample migrates corresponding to the variation in composition with respect to seasons (Fig. 9), $\mathrm{Na}-\mathrm{Ca}-\mathrm{Cl}-\mathrm{HCO}_{3}$ (PRM) to $\mathrm{Na}-\mathrm{Cl}(\mathrm{SWM})$ to $\mathrm{Ca}-\mathrm{HCO}_{3}$ (NEM) to Mixed $\mathrm{Na}-\mathrm{Mg}-\mathrm{Cl}-\mathrm{HCO}_{3}(\mathrm{POM})$. In order to understand groundwater flow and geochemistry (Dalton and Upchurch 1978) is planned to delineate variability. In the POM season, sample persistence in the field of $\mathrm{Ca}^{2+}-\mathrm{Mg}^{2+}-\mathrm{HCO}_{3}{ }^{-}$type can be seen indicating natural recharge phase, mainly owing to interaction between groundwater and the aquifer matrix, Chidambaram 2000, Drever 1997). Majority of the POM samples show dominance of $\mathrm{Ca}^{2+}-\mathrm{Na}^{+}-\mathrm{HCO}_{3}{ }^{-}-\mathrm{Cl}$-facies. Due to irrigation and over-exploitation processes, these samples can be affected by farming processes (Thivya et al. 2013) during this period. Subsequently, in PRM and SWM, $\mathrm{Na}^{+}-\mathrm{Ca}^{2+}-\mathrm{HCO}_{3}{ }^{-}-\mathrm{Cl}^{-}$type was inferred due to the integrated process like ion exchange process and natural weathering (Thivya et al. 2015). Lesser $\mathrm{Ca}^{2+}$ and $\mathrm{Mg}^{2+}$ in the groundwater samples reflect ion exchange of $\mathrm{Na}^{+}$from aquifer matrix during pre-monsoon season.

\section{Statistical analysis}

\section{Correlation matrix}

Correlation analysis and PCA were adopted for the statistical interpretation. This PCA analysis is used to identify the source of a particular ion by correlating each other (Chidambaram et al. 2014). The correlation shows that there is an excellent correlation observed between $\mathrm{Ca}-\mathrm{Mg}$, $\mathrm{Ca}-\mathrm{Na}, \mathrm{Ca}-\mathrm{Cl}, \mathrm{Mg}-\mathrm{Cl}, \mathrm{Na}-\mathrm{Cl}$ and $\mathrm{SO}_{4}$ in PRM. There is a weak association between other parameters like $\mathrm{pH}$, $\mathrm{F}, \mathrm{PO}_{4}, \mathrm{SO}_{4}$ and $\mathrm{H}_{4} \mathrm{SiO}_{4}$. $\mathrm{Cl}$ displays a strong correlation with $\mathrm{Ca}, \mathrm{Mg}$ and $\mathrm{HCO}_{3}$, suggesting secondary salt leaching, and chemical weathering suggest major correlation of $\mathrm{HCO}_{3}$ with $\mathrm{Ca}, \mathrm{Mg}$ and $\mathrm{pH}$ (Chidambaram et al. 2008). The weak positive association between $\mathrm{SO}_{4}, \mathrm{PO}_{4}, \mathrm{NO}_{3}$ and $\mathrm{H}_{4} \mathrm{SiO}_{4}$ demonstrates the effect of farming activities.

The connection between $\mathrm{Ca}$ and $\mathrm{Mg}, \mathrm{Na}, \mathrm{Cl}, \mathrm{SO}_{4}, \mathrm{EC}$, between $\mathrm{Mg}$ and $\mathrm{Na}, \mathrm{SO}_{4}, \mathrm{EC}$, between $\mathrm{Na}$ and $\mathrm{Cl}, \mathrm{NO}_{3}$, $\mathrm{SO}_{4}, \mathrm{EC}$, between $\mathrm{Cl}$ and $\mathrm{SO}_{4}, \mathrm{EC}$, between $\mathrm{NO}_{3}$ and $\mathrm{EC}$ also between $\mathrm{SO}_{4}$ and $\mathrm{EC}$, show strong to excellent correlation during SWM (Table 8) suggesting the processes of leaching and weathering. Chloride demonstrates a strong association with $\mathrm{Mg}$, and $\mathrm{Na}$ reiterating the process of secondary salt leaching. Chemical weathering is demonstrated by the important association of $\mathrm{HCO}_{3}$ with $\mathrm{Mg}$ and $\mathrm{K}$ (Srinivasamoorthy et al. 2009). The effect of dilution may be due to a weak positive correlation between $\mathrm{SO}_{4}, \mathrm{PO}_{4}, \mathrm{NO}_{3}$ and other ions.

There is a strong correlation between $\mathrm{Ca}$ and $\mathrm{Cl}, \mathrm{Mg}$, $\mathrm{EC} ; \mathrm{Mg}$ with $\mathrm{Cl}$; $\mathrm{EC}$ with $\mathrm{Na}$ and $\mathrm{Cl}$ (Table 7) during NEM. There is a weak correlation with all the other ions between $\mathrm{SO}_{4}, \mathrm{PO}_{4}$ and $\mathrm{H}_{4} \mathrm{SiO}_{4}$. $\mathrm{Cl}$ displays a strong correlation with $\mathrm{Ca}, \mathrm{Mg}, \mathrm{Na}$ and $\mathrm{HCO}_{3}$, suggesting secondary salt leaching and correlation of $\mathrm{HCO}_{3}$ with other ions $(\mathrm{Ca}, \mathrm{Mg}, \mathrm{Na}$ and $\mathrm{K}$ ) reflect chemical weathering (Karmegam et al. 2012).

There is a strong correlation between $\mathrm{Ca}$ and $\mathrm{Na}, \mathrm{Cl}$, $\mathrm{HCO}_{3}, \mathrm{PO}_{4}, \mathrm{EC} ; \mathrm{Mg}$ with $\mathrm{Na}, \mathrm{Cl}$ and $\mathrm{EC}$; $\mathrm{Na}$ with $\mathrm{Cl}, \mathrm{HCO}_{3}$, $\mathrm{PO}_{4}$ and $\mathrm{EC} ; \mathrm{Cl}$ with $\mathrm{PO}_{4}, \mathrm{EC}, \mathrm{HCO}_{3}$ and $\mathrm{PO}_{4}$ showing a positive correlation with $\mathrm{EC}$. $\mathrm{Cl}$ shows a good correlation with $\mathrm{Ca}, \mathrm{Mg}, \mathrm{Na}$ and $\mathrm{HCO}_{3}$ suggesting secondary salt leaching and correlation between $\mathrm{HCO}_{3}$ and $\mathrm{Ca}, \mathrm{Mg}, \mathrm{Na}$, and $\mathrm{K}$ suggests chemical weathering. A strong correlation with $\mathrm{Ca}$, $\mathrm{Cl}, \mathrm{HCO}_{3}, \mathrm{Na}, \mathrm{K}$ and $\mathrm{PO}_{4}$ suggests the impact of anthropogenic sources on the system.

\section{Factor analysis (pre-monsoon)}

FA has resulted in four important variables that explain $64.2 \%$ of the pre-monsoon dataset's total data variability (TDV). The ion association in Factor I represents $\mathrm{Ca}, \mathrm{Mg}$, $\mathrm{Na}$, and $\mathrm{Cl}$ with a TDV of $30.9 \%$, suggesting secondary salt leaching. This aspect clearly demonstrates that the influence 
Table 7 Correlation matrix of hydrogeochemical parameters for northeast and post-monsoon seasons

\begin{tabular}{|c|c|c|c|c|c|c|c|}
\hline & $\mathrm{Ca}$ & $\mathrm{Mg}$ & $\mathrm{Na}$ & $\mathrm{K}$ & $\mathrm{F}$ & $\mathrm{Cl}$ & $\mathrm{HCO}_{3}$ \\
\hline \multicolumn{8}{|l|}{ NEM } \\
\hline $\mathrm{Ca}$ & 1 & & & & & & \\
\hline $\mathrm{Mg}$ & 0.68 & 1 & & & & & \\
\hline $\mathrm{Na}$ & 0.34 & 0.39 & 1 & & & & \\
\hline $\mathrm{K}$ & 0.22 & 0.18 & 0.46 & 1 & & & \\
\hline $\mathrm{F}$ & -0.13 & -0.13 & 0.08 & -0.01 & 1 & & \\
\hline $\mathrm{Cl}$ & 0.79 & 0.82 & 0.69 & 0.429 & -0.01 & 1 & \\
\hline $\mathrm{HCO}_{3}$ & 0.24 & 0.13 & 0.03 & -0.05 & 0.43 & -0.08 & 1 \\
\hline $\mathrm{NO}_{3}$ & 0.25 & 0.32 & 0.06 & 0.191 & -0.05 & 0.11 & 0.43 \\
\hline $\mathrm{PO}_{4}$ & 0.29 & 0.37 & 0.25 & 0.143 & 0.19 & 0.34 & 0.08 \\
\hline $\mathrm{SO}_{4}$ & 0.02 & -0.18 & 0.04 & -0.04 & 0.14 & 0.00 & -0.21 \\
\hline $\mathrm{H}_{4} \mathrm{SiO}_{4}$ & -0.33 & -0.35 & -0.21 & 0.005 & -0.04 & -0.30 & -0.10 \\
\hline $\mathrm{pH}$ & -0.12 & -0.19 & -0.15 & -0.07 & 0.01 & -0.19 & 0.17 \\
\hline $\mathrm{EC}$ & 0.56 & 0.69 & 0.60 & 0.185 & -0.07 & 0.72 & 0.18 \\
\hline Temp & -0.05 & -0.06 & -0.17 & -0.04 & 0.19 & -0.09 & -0.04 \\
\hline \multicolumn{8}{|l|}{ POM } \\
\hline $\mathrm{Ca}$ & 1 & & & & & & \\
\hline $\mathrm{Mg}$ & 0.28 & 1 & & & & & \\
\hline $\mathrm{Na}$ & 0.58 & 0.57 & 1 & & & & \\
\hline $\mathrm{K}$ & 0.49 & 0.13 & 0.51 & 1 & & & \\
\hline $\mathrm{F}$ & -0.02 & 0.04 & 0.25 & 0.02 & 1 & & \\
\hline $\mathrm{Cl}$ & 0.68 & 0.66 & 0.80 & 0.39 & 0.03 & 1 & \\
\hline $\mathrm{HCO}_{3}$ & 0.54 & 0.49 & 0.67 & 0.39 & 0.21 & 0.42 & 1 \\
\hline $\mathrm{NO}_{3}$ & 0.37 & 0.08 & 0.30 & 0.26 & 0.06 & 0.23 & 0.28 \\
\hline $\mathrm{PO}_{4}$ & 0.63 & 0.21 & 0.59 & 0.43 & 0.17 & 0.56 & 0.42 \\
\hline $\mathrm{SO}_{4}$ & 0.19 & 0.26 & 0.41 & 0.33 & -0.02 & 0.35 & 0.19 \\
\hline $\mathrm{H}_{4} \mathrm{SiO}_{4}$ & -0.03 & -0.18 & -0.21 & -0.02 & 0.20 & -0.16 & -0.13 \\
\hline $\mathrm{pH}$ & -0.28 & -0.02 & 0.21 & -0.02 & 0.29 & -0.10 & 0.15 \\
\hline $\mathrm{EC}$ & 0.70 & 0.58 & 0.91 & 0.53 & 0.11 & 0.83 & 0.60 \\
\hline \multirow[t]{2}{*}{ Temp } & 0.07 & -0.04 & 0.25 & 0.11 & 0.25 & 0.02 & 0.04 \\
\hline & $\mathrm{NO}_{3}$ & $\mathrm{PO}_{4}$ & $\mathrm{SO}_{4}$ & $\mathrm{H}_{4} \mathrm{SiO}_{4}$ & $\mathrm{pH}$ & $\mathrm{EC}$ & Temp \\
\hline
\end{tabular}

\section{NEM}

$\mathrm{Ca}$

$\mathrm{Mg}$

$\mathrm{Na}$

$\mathrm{K}$

$\mathrm{F}$

$\mathrm{Cl}$

$\mathrm{HCO}_{3}$

$\mathrm{NO}_{3} \quad 1$

$\begin{array}{lll}\mathrm{PO}_{4} & 0.06 & 1\end{array}$

$\begin{array}{llll}\mathrm{SO}_{4} & -0.35 & -0.12 & 1\end{array}$

$\begin{array}{llll}\mathrm{H}_{4} \mathrm{SiO}_{4} & -0.04 & -0.27 & 0.03\end{array}$

$\mathrm{pH}$

$-0.09 \quad-0.02$

EC

$0.19 \quad 0.41$

Temp

$-0.07$

$-0.08$

0.01

$-0.07$

0.04

$-0.10$

POM

$\mathrm{Ca}$

$\mathrm{Mg}$ 
Table 7 (continued)

\begin{tabular}{|c|c|c|c|c|c|c|c|}
\hline & $\mathrm{NO}_{3}$ & $\mathrm{PO}_{4}$ & $\mathrm{SO}_{4}$ & $\mathrm{H}_{4} \mathrm{SiO}_{4}$ & $\mathrm{pH}$ & EC & Temp \\
\hline \multicolumn{8}{|l|}{$\mathrm{Na}$} \\
\hline \multicolumn{8}{|l|}{ K } \\
\hline \multicolumn{8}{|l|}{$\mathrm{F}$} \\
\hline \multicolumn{8}{|l|}{$\mathrm{Cl}$} \\
\hline \multicolumn{8}{|l|}{$\mathrm{HCO}_{3}$} \\
\hline $\mathrm{NO}_{3}$ & 1 & & & & & & \\
\hline $\mathrm{PO}_{4}$ & 0.20 & 1 & & & & & \\
\hline $\mathrm{SO}_{4}$ & 0.33 & -0.04 & 1 & & & & \\
\hline $\mathrm{H}_{4} \mathrm{SiO}_{4}$ & -0.19 & -0.14 & 0.02 & 1 & & & \\
\hline $\mathrm{pH}$ & -0.05 & -0.04 & -0.04 & -0.06 & 1 & & \\
\hline $\mathrm{EC}$ & 0.34 & 0.58 & 0.49 & -0.18 & 0.01 & 1 & \\
\hline Temp & 0.04 & 0.08 & 0.33 & 0.11 & 0.17 & 0.26 & 1 \\
\hline
\end{tabular}

of domestic sewage source (Ruiz et al. 1990; Voudouris et al. 1997). This may also be due to the influence of high $\mathrm{Na}^{+}$, as calcareous and dolomite has $\mathrm{Na}^{+}$as a result of deposition during the shallow marine conditions and due to the existence of skeletal remains (Billings and Ragland 1968). In the hydrogeochemical setting, factor II indicates (Table 9) the effect of $\mathrm{Na}, \mathrm{NO}_{3}$ and $\mathrm{SO}_{4}$. The loading of nitrate and sulphate concentration is primarily due to the weathering of the gypsum found in the cretaceous formation. Factor III with $11.3 \%$ of total data variability demonstrates positive loading of $\mathrm{K}, \mathrm{PO}_{4}$ indicating human influence such as septic tanks, residential water softeners, and fertilizer (Vengosh and Keren 1996). Factor IV shows $\mathrm{F}$ and $\mathrm{HCO}_{3}$ enrichments with TDV $7.87 \%$ (Table 9). The loading of $\mathrm{HCO}_{3}$ and $\mathrm{F}$ is due to the high alkaline water, favouring release mechanism and enhancing the mobility of F ions in the groundwater.

\section{Factor analysis (southwest monsoon)}

Four factors with eigenvalue greater than 1 were extracted during this season. The total data variability of $39.9 \%$ was observed for first factor with loadings of $\mathrm{EC}, \mathrm{Ca}, \mathrm{Mg}, \mathrm{Na}, \mathrm{Cl}$, SO4 suggesting secondary salt leaching (Tables 8, 9). Factor II (11.2\% TDV) has a loading of $\mathrm{F}$ and $\mathrm{HCO}_{3}$. Higher positive loading of $\mathrm{F}$ and $\mathrm{HCO}_{3}$ and negative loading of $\mathrm{pH}$ and temperature show that the $\mathrm{pH}$ of the carbonate rocks regulates the release of $\mathrm{F}$ during this season. Factor III shows $8.8 \% \mathrm{TDV}$ with loadings of $\mathrm{H}_{4} \mathrm{SiO}_{4}$ and temperature reflecting the thermodynamic constrains on the release of silica to the groundwater. $7.7 \%$ of TDV with positive loading of $\mathrm{PO}_{4}$ and $\mathrm{K}$ was observed in factor IV, which suggests anthropogenic sources as discussed in the previous season (Vengosh and Keren 1996).

\section{Factor analysis (northeast monsoon)}

The season data shows four prominent factors and the Factor I is expressed by a TDV of $31.3 \%$ with a positive loading of electrical conductivity, $\mathrm{Ca}^{2+}, \mathrm{Mg}^{2+}, \mathrm{Na}^{+}$and $\mathrm{Cl}$ measured in groundwater suggest that the adsorbed or other types of solid solution within the geological matrix join the aqueous media upon dissolution of the matrix. It could also be because that the $\mathrm{Cl}$ in groundwater is leached from the sediments deposited in marine environments. However, the connate sea water may be washed out due to several reasons within marine sediments, including the aquifer properties like permeability and porosity, the sedimentary basin structure, and distance from the region of recharge (Johns 1968). A TDV of $11.8 \%$ was observed for factor II (Table 9) with a positive $\mathrm{NO}_{3}{ }^{-}$loading suggesting mixing of domestic wastewater or other anthropogenic activity. The positive loading of $\mathrm{Na}$ and $\mathrm{K}$ suggesting intense weathering in Factor III (Prasanna et al. 2009). The positive loadings of $\mathrm{F}$ and $\mathrm{pH}$ were observed as fourth factor; similar process was discussed in previous season.

\section{Factor analysis (post-monsoon)}

The maximum number of factors was extracted in this season due to the geochemical complexity with a TDV of $72.43 \%$. $\mathrm{Ca}, \mathrm{Na}, \mathrm{K}, \mathrm{Cl} \mathrm{HCO}_{3}, \mathrm{PO}_{4}$ and EC (Table 9) reflect Factor 1 and as discussed earlier the factor explains the dissolution of secondary salts. $\mathrm{Mg}, \mathrm{Cl}, \mathrm{EC}$ with $11.5 \%$ of TDV is loaded in Factor II, which represents diffuse groundwater pollution due to agricultural practices (especially in the areas utilizing dolomite as neutralizers, agricultural additives). $\mathrm{SO}_{4}$ and temperature, indicating the temperature controlled factor, are expressed by factor III with $9.2 \%$ TDV. The $\mathrm{pH}$ shows the dominance in the factor IV representing the base ion exchange and Factor $\mathrm{V}$ was loaded with $\mathrm{H}_{4} \mathrm{SiO}_{4}$ reflecting 
Table 8 Correlation matrix of hydrogeochemical parameters for pre- and southwest monsoon seasons

\begin{tabular}{|c|c|c|c|c|c|c|c|}
\hline & $\mathrm{Ca}$ & $\mathrm{Mg}$ & $\mathrm{Na}$ & $\mathrm{K}$ & $\mathrm{F}$ & $\mathrm{Cl}$ & $\mathrm{HCO}_{3}$ \\
\hline \multicolumn{8}{|l|}{ PRM } \\
\hline $\mathrm{Ca}$ & 1 & & & & & & \\
\hline $\mathrm{Mg}$ & 0.71 & 1 & & & & & \\
\hline $\mathrm{Na}$ & 0.52 & 0.64 & 1 & & & & \\
\hline $\mathrm{K}$ & 0.18 & 0.13 & 0.10 & 1 & & & \\
\hline F & -0.17 & -0.09 & 0.22 & -0.15 & 1 & & \\
\hline $\mathrm{Cl}$ & 0.76 & 0.83 & 0.88 & 0.05 & 0.00 & 1 & \\
\hline $\mathrm{HCO}_{3}$ & -0.03 & 0.17 & 0.39 & 0.07 & 0.29 & 0.19 & 1 \\
\hline $\mathrm{NO}_{3}$ & 0.15 & 0.20 & 0.48 & 0.21 & 0.28 & 0.25 & 0.20 \\
\hline $\mathrm{PO}_{4}$ & 0.06 & 0.02 & 0.04 & 0.42 & -0.06 & -0.01 & -0.04 \\
\hline $\mathrm{SO}_{4}$ & 0.38 & 0.30 & 0.53 & 0.21 & 0.32 & 0.41 & 0.14 \\
\hline $\mathrm{H}_{4} \mathrm{SiO}_{4}$ & 0.00 & -0.07 & -0.16 & 0.09 & 0.12 & -0.16 & -0.04 \\
\hline $\mathrm{pH}$ & -0.59 & -0.40 & -0.12 & -0.18 & 0.24 & -0.31 & -0.01 \\
\hline $\mathrm{EC}$ & 0.45 & 0.44 & 0.57 & 0.07 & 0.10 & 0.59 & 0.07 \\
\hline Temp & 0.09 & -0.01 & -0.06 & -0.06 & -0.13 & 0.02 & -0.05 \\
\hline \multicolumn{8}{|l|}{ SWM } \\
\hline $\mathrm{Ca}$ & 1 & & & & & & \\
\hline $\mathrm{Mg}$ & 0.65 & 1 & & & & & \\
\hline $\mathrm{Na}$ & 0.65 & 0.65 & 1 & & & & \\
\hline $\mathrm{K}$ & 0.29 & 0.12 & 0.01 & 1 & & & \\
\hline $\mathrm{F}$ & 0.07 & 0.18 & 0.27 & -0.19 & 1 & & \\
\hline $\mathrm{Cl}$ & 0.78 & 0.76 & 0.95 & 0.10 & 0.17 & 1 & \\
\hline $\mathrm{HCO}_{3}$ & 0.00 & 0.18 & 0.26 & -0.11 & 0.32 & 0.10 & 1 \\
\hline $\mathrm{NO}_{3}$ & 0.41 & 0.42 & 0.61 & 0.20 & 0.23 & 0.53 & 0.30 \\
\hline $\mathrm{PO}_{4}$ & -0.07 & -0.11 & -0.08 & 0.23 & -0.09 & -0.10 & 0.11 \\
\hline $\mathrm{SO}_{4}$ & 0.68 & 0.70 & 0.86 & 0.10 & 0.29 & 0.87 & 0.15 \\
\hline $\mathrm{H}_{4} \mathrm{SiO}_{4}$ & -0.16 & -0.24 & -0.36 & 0.13 & 0.01 & -0.32 & -0.07 \\
\hline $\mathrm{pH}$ & -0.52 & -0.43 & -0.26 & -0.20 & -0.01 & -0.37 & -0.01 \\
\hline $\mathrm{EC}$ & 0.76 & 0.79 & 0.93 & 0.15 & 0.27 & 0.95 & 0.19 \\
\hline \multirow[t]{2}{*}{ Temp } & 0.15 & 0.14 & 0.05 & 0.07 & -0.05 & 0.09 & 0.07 \\
\hline & $\mathrm{NO}_{3}$ & $\mathrm{PO}_{4}$ & $\mathrm{SO}_{4}$ & $\mathrm{H}_{4} \mathrm{SiO}_{4}$ & $\mathrm{pH}$ & $\mathrm{EC}$ & Temp \\
\hline
\end{tabular}

\section{PRM}

$\mathrm{Ca}$

$\mathrm{Mg}$

$\mathrm{Na}$

K

F

$\mathrm{Cl}$

$\mathrm{HCO}_{3}$

$\mathrm{NO}_{3}$

$\mathrm{PO}_{4} \quad 0.06 \quad 1$

$\mathrm{SO}_{4}$

$\mathrm{H}_{4} \mathrm{SiO}_{4}$

0.48

$-0.12$

$-0.02$

$\mathrm{pH}$

$-0.01$

EC

0.29

0.35

$-0.09$

$-0.18$

$-0.04$

$-0.07$

1

$\begin{array}{ll}-0.28 & 1\end{array}$

$-0.07$

0.48

$-0.12$

$-0.23$

$-0.24$

$-0.06$

$-0.01$

$-0.09$

$-0.12$

1

SWM

$\mathrm{Ca}$

$\mathrm{Mg}$ 
Table 8 (continued)

\begin{tabular}{|c|c|c|c|c|c|c|c|}
\hline & $\mathrm{NO}_{3}$ & $\mathrm{PO}_{4}$ & $\mathrm{SO}_{4}$ & $\mathrm{H}_{4} \mathrm{SiO}_{4}$ & $\mathrm{pH}$ & EC & Temp \\
\hline \multicolumn{8}{|l|}{$\mathrm{Na}$} \\
\hline \multicolumn{8}{|l|}{ K } \\
\hline \multicolumn{8}{|l|}{$\mathrm{F}$} \\
\hline \multicolumn{8}{|l|}{$\mathrm{Cl}$} \\
\hline \multicolumn{8}{|l|}{$\mathrm{HCO}_{3}$} \\
\hline $\mathrm{NO}_{3}$ & 1 & & & & & & \\
\hline $\mathrm{PO}_{4}$ & -0.04 & 1 & & & & & \\
\hline $\mathrm{SO}_{4}$ & 0.51 & -0.08 & 1 & & & & \\
\hline $\mathrm{H}_{4} \mathrm{SiO}_{4}$ & -0.15 & 0.16 & -0.35 & 1 & & & \\
\hline $\mathrm{pH}$ & -0.24 & 0.17 & -0.22 & -0.11 & 1 & & \\
\hline $\mathrm{EC}$ & 0.62 & -0.08 & 0.82 & -0.33 & -0.38 & 1 & \\
\hline Temp & -0.04 & 0.05 & 0.06 & 0.15 & -0.15 & 0.10 & 1 \\
\hline
\end{tabular}

Table 9 Factor analysis of the PRM, SWM, NEM and POM samples (Varimax rotated)

\begin{tabular}{|c|c|c|c|c|c|c|c|c|c|}
\hline & 1 & 2 & 3 & 4 & 1 & 2 & 3 & 4 & 5 \\
\hline$P R M$ & & & & & SWM & & & & \\
\hline $\mathrm{Ca}$ & 0.85 & 0.29 & 0.10 & -0.17 & 0.83 & -0.18 & 0.26 & 0.06 & \\
\hline $\mathrm{Mg}$ & 0.84 & 0.27 & -0.03 & 0.06 & 0.81 & 0.07 & 0.18 & -0.07 & \\
\hline $\mathrm{Na}$ & 0.58 & 0.60 & -0.06 & 0.38 & 0.91 & 0.22 & -0.10 & -0.03 & \\
\hline K & 0.05 & 0.31 & 0.72 & -0.20 & 0.21 & -0.32 & 0.25 & 0.66 & \\
\hline $\mathrm{F}$ & -0.22 & 0.21 & -0.07 & 0.76 & 0.16 & 0.73 & 0.05 & -0.22 & \\
\hline $\mathrm{Cl}$ & 0.82 & 0.44 & -0.13 & 0.11 & 0.96 & 0.02 & 0.01 & -0.03 & \\
\hline $\mathrm{HCO}_{3}$ & 0.16 & 0.06 & -0.06 & 0.69 & 0.11 & 0.77 & 0.02 & 0.15 & \\
\hline $\mathrm{NO}_{3}$ & 0.04 & 0.56 & 0.22 & 0.38 & 0.62 & 0.32 & -0.01 & 0.20 & \\
\hline $\mathrm{PO}_{4}$ & 0.03 & -0.02 & 0.80 & -0.02 & -0.12 & 0.12 & -0.07 & 0.84 & \\
\hline $\mathrm{SO}_{4}$ & 0.14 & 0.82 & -0.01 & 0.14 & 0.89 & 0.16 & -0.09 & -0.02 & \\
\hline $\mathrm{H}_{4} \mathrm{SiO}_{4}$ & 0.10 & -0.47 & 0.58 & 0.33 & -0.41 & 0.06 & 0.64 & 0.22 & \\
\hline $\mathrm{pH}$ & -0.71 & 0.24 & -0.25 & 0.10 & -0.43 & 0.17 & -0.65 & 0.14 & \\
\hline $\mathrm{EC}$ & 0.36 & 0.64 & -0.15 & 0.02 & 0.95 & 0.13 & 0.04 & 0.01 & \\
\hline Temp & 0.18 & -0.20 & -0.20 & -0.23 & 0.06 & 0.10 & 0.62 & 0.029 & \\
\hline$N E M$ & & & & & POM & & & & \\
\hline $\mathrm{Ca}$ & 0.76 & 0.13 & 0.08 & -0.17 & 0.85 & 0.15 & 0.10 & -0.26 & 0.04 \\
\hline $\mathrm{Mg}$ & 0.83 & 0.24 & 0.10 & -0.22 & 0.28 & 0.85 & -0.05 & 0.09 & -0.09 \\
\hline $\mathrm{Na}$ & 0.51 & -0.13 & 0.67 & 0.00 & 0.72 & 0.47 & 0.26 & 0.33 & -0.14 \\
\hline $\mathrm{K}$ & 0.13 & 0.05 & 0.72 & -0.21 & 0.63 & -0.02 & 0.35 & -0.08 & -0.03 \\
\hline $\mathrm{F}$ & -0.14 & 0.11 & 0.32 & 0.71 & 0.19 & -0.09 & 0.06 & 0.68 & 0.31 \\
\hline $\mathrm{Cl}$ & 0.83 & -0.08 & 0.40 & -0.25 & 0.70 & 0.56 & 0.07 & -0.04 & -0.05 \\
\hline $\mathrm{HCO} 3$ & 0.16 & 0.62 & -0.08 & 0.45 & 0.62 & 0.30 & 0.03 & 0.30 & -0.17 \\
\hline NO3 & 0.13 & 0.83 & 0.10 & -0.18 & 0.38 & -0.18 & 0.47 & -0.11 & -0.49 \\
\hline PO4 & 0.58 & 0.01 & -0.02 & 0.10 & 0.87 & -0.05 & -0.16 & 0.10 & -0.02 \\
\hline $\mathrm{SO} 4$ & -0.03 & -0.70 & -0.02 & -0.04 & 0.12 & 0.28 & 0.81 & -0.06 & -0.05 \\
\hline $\mathrm{H} 4 \mathrm{SiO} 4$ & -0.58 & 0.07 & 0.30 & -0.03 & -0.05 & -0.15 & 0.11 & -0.02 & 0.86 \\
\hline $\mathrm{pH}$ & -0.02 & -0.07 & -0.16 & 0.69 & -0.14 & 0.00 & 0.05 & 0.82 & -0.21 \\
\hline $\mathrm{EC}$ & 0.82 & 0.08 & 0.27 & 0.01 & 0.73 & 0.50 & 0.33 & 0.08 & -0.09 \\
\hline Temp & -0.01 & -0.05 & -0.40 & -0.13 & 0.04 & -0.03 & 0.64 & 0.35 & 0.27 \\
\hline
\end{tabular}


silicate dissolution during this season (Chidambaram et al. 2008).

\section{Conclusion}

In the study area, the chemical composition of groundwater is altered by hydrogeochemical processes and thus varies with space and time. The four-season spatial representation of the EC shows that higher concentrations were found in the central and southern parts of the studied region chiefly covered by hard rock region, reflecting greater residence time. Thus, the spatial distribution of the EC also reflects the influence of lithology variation. Since the study area is dominated by NEM monsoon rainfall, the flow in the river improves weathering and recharge along with domestic sewage and even along the river course due to the landfill leachates. The Piper plot reveals there is a compositional migration was observed by $\mathrm{Ca}-\mathrm{HCO}_{3}$ type in the predominant monsoon and the POM season. The utility of water for different purposes classified by adopting different indices show that PRM and SWM groundwater quality are generally poor with higher dissolved ions. Majority of the samples were inferred to be unsuitable for agricultural and domestic purposes during PRM and SWM. The major sources irrespective of the season were inferred to be the leaching and dissolution apart from silicate weathering and fluoride dissolution. Lithologically, the presence of clay in the sedimentary region has favoured the ion exchange process. There was an interplay of the anthropogenic factor on the hydrogeochemistry of the region, especially, during the monsoon periods due to the onset of the agricultural activities. Thus, the study of the groundwater in four prominent seasons provides a synoptic overview of the hydrogeochemical process in the study area, which can help in the sustainable management of the water resource.

Funding No funding was availed for this research work.

\section{Compliance with Ethical Standards}

Conflict of interest The authors declare that they have no conflict of interest.

Consent for publication This article submitted with consent of all the authors.

Human and animal rights Also this research work involves only human participants not animals.

Open Access This article is licensed under a Creative Commons Attribution 4.0 International License, which permits use, sharing, adaptation, distribution and reproduction in any medium or format, as long as you give appropriate credit to the original author(s) and the source, provide a link to the Creative Commons licence, and indicate if changes were made. The images or other third party material in this article are included in the article's Creative Commons licence, unless indicated otherwise in a credit line to the material. If material is not included in the article's Creative Commons licence and your intended use is not permitted by statutory regulation or exceeds the permitted use, you will need to obtain permission directly from the copyright holder. To view a copy of this licence, visit http://creativecommons.org/licenses/by/4.0/.

\section{References}

Acharya T, Kumbhakar S, Prasad R (2017) Delineation of potential groundwater recharge zones in the coastal area of north-eastern India using geoinformatics. Sustain Water Resour Manag 5:533540. https://doi.org/10.1007/s40899-017-0206-4

Adimalla N (2019) Groundwater quality for drinking and irrigation purposes and potential health risks assessment: a case study from semi-arid region of South India. Expos Health 11(2):109-123. https://doi.org/10.1007/s12403-018-0288-8

Adimalla N (2020) Controlling factors and mechanism of groundwater quality variation in semiarid region of South India: an approach of water quality index (WQI) and health risk assessment (HRA). Environ Geochem Health 42(6):1725-1752. https://doi.org/10. 1007/s10653-019-00374-8

Adimalla N, Qian H (2021) Groundwater chemistry, distribution and potential health risk appraisal of nitrate enriched groundwater: a case study from the semi-urban region of South India. Ecotoxicol Environ Saf 207:111277. https://doi.org/10.1016/j.ecoenv.2020. 111277

Adimalla N, Venkatayogi S (2018) Geochemical characterization and evaluation of groundwater suitability for domestic and agricultural utility in semi-arid region of Basara, Telangana State, South India. Appl Water Sci 8:44. https://doi.org/10.1007/s13201-018-0682-1

Adimalla N, Qian H, Li P (2020a) Entropy water quality index and probabilistic health risk assessment from geochemistry of groundwaters in hard rock terrain of Nanganur County. South India Geochem 80(4):125544. https://doi.org/10.1016/j.chemer.2019. 125544

Adimalla N, Qian H, Nandan MJ (2020b) Groundwater chemistry integrating the pollution index of groundwater and evaluation of potential human health risk: a case study from hard rock terrain of south India. Ecotoxicol Environ Saf 206:111217. https://doi. org/10.1016/j.ecoenv.2020.111217

Adithya VS, Chidambaram S, Tirumalesh K (2016) Assessment of sources for higher Uranium concentration in ground waters of the Central Tamilnadu, India. IOP Conf Ser Mater Sci Eng 121:012009. https://doi.org/10.1088/1757-899x/121/1/012009

Allan freeze, R., Cherry J.A, (1979) Groundwater, Prentice-Hall Inc., Englewood Cliffs, N.J recharge in parts of Sokoto Basin. Nigeria J Environ Hydrol 14:1-17

Anandhan P (2005) Hydrogeochemical studies in and around Neyveli mining region, Tamilnadu. Thesis, India

APHA (1998) Standard methods: for the examination of water and waste- water. American Public Health Association, Washington

Aragu'as LJ (2003) Proceedings of 18th salt water intrusion meeting. In: IGME. pp 365-371

Banerji RK (1979) On the occurrence of Tertiary algal reefs in the Cauvery basin and their stratigraphic relationship. Geol Surv India Misc., pp 181-196

Bertrand A, Nathalie D, Cédric D (2006) In: International symposium Aquifers Systems Management. France

Carroll RWH, Pohll GM, Hershey RL (2009) An unconfined groundwater model of the Death Valley Regional Flow System and a 
comparison to its confined predecessor. J Hydrol 373:316-328. https://doi.org/10.1016/j.jhydrol.2009.05.006

Champ DR, Gulens J, Jackson RE (1979) Oxidation-reduction sequences in ground water flow systems. Can J Earth Sci 16:1223. https://doi.org/10.1139/e79-002

Chandra SJ, Thergaonkar VP, Sharma R (1981) Water quality and dental fluorosis. Ind J Pub Health 25:47-51

Chapelle FH, Zelibor JL, Grimes DJ, Knobel LRL (1987) Bacteria in deep coastal plain sediments of Maryland: a possible source of CO2 to groundwater. Water Resour Res 23:1625-1632. https:// doi.org/10.1029/wr023i008p01625

Chidambaram S (2000) Hydrogeochemical studies of groundwater in Periyar district, Tamilnadu. Thesis, India

Chidambaram S, Ramanathan AL, Vasudevan S (2004) Fluoride removal studies in water using natural materials : technical note. Water SA. https://doi.org/10.4314/wsa.v29i3.4936

Chidambaram S, Vijayakumar V, Srinivasamoorthy K, Anandhan P, Prasanna MV, Vasudevan S (2007) A study on variation in Ionic Composition of Aqueous System in different lithounits around Perambalur region, Tamil Nadu. Geol Soc India 70:1061-1069

Chidambaram S, Ramanathan AL, Anandhan P, Srinivasamoorthy K, Prasanna MV, Vasudevan S (2008) A statistical approach to identify the hydrogeochemically active regimes in ground waters of Erode district, Tamilnadu. Asian J Water Environ Pollut 5:123-135

Chidambaram S, Ramanathan AL, Prasanna MV (2009) Study on the hydrogeochemical characteristics in groundwater, post- and pretsunami scenario, from Portnova to Pumpuhar, southeast coast of India. Environ Monit Assess 169:553-568. https://doi.org/10. 1007/s10661-009-1196-y

Chidambara S, John Peter A, Prasanna MV, Karmegam U, Balaji K, Ramesh R, Paramaguru P, Pethaperua S (2010) A study on the impact of landuse pattern in the groundwater quality in and around Madurai region South India-using GIS techniques. Online J Earth Sci 4(1):27-31. https://doi.org/10.3923/ojesci.2010.27.31

Chidambaram S, Karmegam U, Prasanna MV, Sasidhar P (2012) A study on evaluation of probable sources of heavy metal pollution in groundwater of Kalpakkam region, South India. Environmentalist 32:371-382. https://doi.org/10.1007/s10669-012-9398-1

Chidambaram S, Prasad MB, Prasanna MV (2014) Evaluation of metal pollution in groundwater in the industrialized environs in and around Dindigul, Tamilnadu, India. Water Qual Expo Health 7:307-317. https://doi.org/10.1007/s12403-014-0150-6

Chidambaram S, Ramanathan AL, Srinivasamoorthy K, and Anandhan P (2003) WATCLAST A computer program for hydrogeochemical studies. Recent trends in hydrogeochemistry (case studies from surface and subsurface waters of selected countries). Capital Publishing, New Delhi, New Delhi

Dalton MG, Upchurch SB (1978) Interpretation of hydrochemical facies by factor analysis. Ground Water 16:228-233. https://doi. org/10.1111/j.1745-6584.1978.tb03229.x

Devaraj N, Chidambaram S, Gantayat RR (2018) An insight on the speciation and genetical imprint of bicarbonate ion in the groundwater along K/T boundary, South India. Arab J Geosci. https://doi. org/10.1007/s12517-018-3622-3

Devaraj N, Chidambaram S, Vasudevan U (2020) Determination of the major geochemical processes of groundwater along the Cretaceous-Tertiary boundary of Trichinopoly, Tamilnadu, India. Acta Geochimica 39:760-781. https://doi.org/10.1007/ s11631-020-00399-2

Devraj N, Chidambaram S, Thivya C, Thilagavathi R (2016) A study on the hydrogeochemical processes groundwater quality of Ariyalur region, Tamilnadu. Int J Curr Res Dev 4:1-13

Emerson W, Bakker AC (1973) The comparative effect of exchangeable $\mathrm{Ca}, \mathrm{Mg}$ and $\mathrm{Na}$ on some soil physical properties of red brown earth soils. 2. The spontaneous dispersion of aggregates in water. Aust J Soil Res 11:151-152

Frankm E (1950) Significance of carbonates in irrigation waters. Soil Sci 69:123-134. https://doi.org/10.1097/00010694-19500 2000-00004

Ghafoor AMA, Shoaib M (1993) Characterization of tube well and hand pump waters in the Faisalabad tehsil Pakistan. J Soil Sci $8: 1-2$

Ghafoor A, Ullah F, Abdullah M (1990) Use of high Mg brackish water for reclamation of saline sodic soil. 1. Soil improvement. Pakistan J Agricu Sci 27:294-298

Govindan A, Ravindran CN, Rangaraju MK (1996) Cretaceous stratigraphy and planktonic foraminiferal zonation of Cauvery Basin, South India. Memoir Geol Soc India 37:155-187

Gronberg JA, Pucci Jr., and Birkelo BA (1991) Hydrogeologic framework of the Potomac-Raritan-Magothy aquifer system, northern Coastal Plain of New Jersey. New jersey geological survey special Bulletin. https://doi.org/10.3133/wri904016

James 1 Drever (1997) The geochemistry of natural waters, 3rd edn. Prentice Hall

Johns MW (1968) Geochemistry of groundwater from upper cretaceous-lower tertiary sand aquifers in South-Western Victoria, Australia. J Hydrol 6:337-357. https://doi.org/10.1016/00221694(68)90054-1

Kanwar JS, Chaudhry ML (1968) Effect of Mg on the uptake of nutrients from the soil. J Res Pb Agric Uni 3:309-319

Karmegam U, Chidamabram S, Sasidhar P, Manivannan R, Manikandan S, Anandhan P (2010) Geochemical characterization of groundwaters of shallow coastal aquifer in and around Kalpakkam, South India. Res J Environ Earth Sci 2:170-177

Karmegam U (2012) A study on the hydrogeochemical modeling of coastal aquifers in and around Kalpakkam. Thesis

Kumar M, Ramanathan AL, Tripathi R (2017) A study of trace element contamination using multivariate statistical techniques and health risk assessment in groundwater of Chhaprola Industrial Area, Gautam Buddha Nagar, Uttar Pradesh, India. Chemosphere 166:135-145. https://doi.org/10.1016/j.chemosphere.2016.09.086

Li S, Wenzhi SG, Han LH, Zhang Q (2008) Water quality in relation to land use and land cover in the upper Han River Basin, China. CATENA 75:216-222. https://doi.org/10.1016/j.catena.2008.06. 005

Loganathan K, Ahamed AJ (2017) Multivariate statistical techniques for the evaluation of groundwater quality of Amaravathi River Basin: South India. Appl Water Sci 7:4633-4649. https://doi.org/ 10.1007/s13201-017-0627-0

Madhavaraju J, Ramasamy S (1999) Rare earth elements in limestones of Kallankurichchi Formation of Ariyalur Group. J Geol Soc India 54:291-301

Madhavaraju J, Ramasamy S (2001) Clay mineral assemblages and rare earth element distribution in the sediments of Ariyalur Group, Tiruchirapalli District, Tamil Nadu -Implication for paleoclimate. Jour Geol Soc India 58:69-77

Manivannan R, Chidambaram S, Anandhan P et al (2011) Study on the Significance of Temporal Ion Chemistry in Groundwater of Dindigul District, Tamilnadu, India. E J Chem 8:938-944. https:// doi.org/10.1155/2011/632968

Mattheß G (1982) The properties of groundwater. Wiley, New York

Mehra M, Oinam B, Singh CK (2016) Integrated assessment of groundwater for agricultural use in Mewat District of Haryana, India using geographical information system (GIS). J Indian Soc Remote Sens 44:747-758. https://doi.org/10.1007/ s12524-015-0541-6

Mishra A (2014) In: Proc. of the 11th Kovacs Colloquium. Ed. Gordon Young, IAHS Publ, France

Mondal NC, Singh VS (2004) A new approach to delineate the groundwater recharge zone in hard rock terrain. In: current science. 
National Geophysical Research Institute, Hyderabad, Andra pradesh, p 10

Olofinlade WS, Daramola SO, Olabode OF (2018) Hydrochemical and statistical modeling of groundwater quality in two constrasting geological terrains of southwestern Nigeria. Model Earth Syst Enviro 4:1405-1421. https://doi.org/10.1007/s40808-018-0486-1

Prasanna MV, Chidambaram S, Shahul Hameed A, Srinivasamoorthy K (2009) Study of evaluation of groundwater in Gadilam basin using hydrogeochemical and isotope data. Environ Monit Assess 168:63-90. https://doi.org/10.1007/s10661-009-1092-5

Prasanna MV, Nagarajan R, Chidambaram S et al (2013) Drip water Geochemistry of Niah Great Cave, NW Borneo, Malaysia: a base line study. Carbonates Evaporites 29:41-54. https://doi.org/10. 1007/s13146-013-0164-3

Qiyan F, Baoping H (2002) Hydrogeochemical simulation of waterrock interaction under water flood recovery in Renqiu Oilfield, Hebei Province, China. Chin J Geochem 21:156-162. https://doi. org/10.1007/bf02873773

Ramanathan S (1979) Tertiary formations of South India. Geol Surv India Misc Publ 45:165-180

Ramasamy S, Banerji RK (1991) Geology, petrography and stratigraphy of pre-Ariyalur sequence in Tiruchirapalli District, Tamil Nadu. J Geol Soc India 37:577-594

Richards LA (1954) Diagnosis and improvement of saline and alkali soils. U.S. Dept. of Agriculture, Washington, D.C.

Ryznar JW (1944) A new index for determining amount of calcium carbonate scale formed by a water. J Am Water Works Assoc 36:472-483. https://doi.org/10.1002/j.1551-8833.1944.tb20016.x

Saravanan K, Srinivasamoorthy K, Gopinath S et al (2016) Investigation of hydrogeochemical processes and groundwater quality in Upper Vellar sub-basin Tamilnadu, India. Arab J Geosci. https:// doi.org/10.1007/s12517-016-2369-y

Saxena V, Ahmed S (2003) Inferring the chemical parameters for the dissolution of fluoride in groundwater. Environ Geol 43:731-736. https://doi.org/10.1007/s00254-002-0672-2

Senthilkumar S, Gowtham B, Sundararajan M et al (2017) Impact of landuse on the groundwater quality along coastal aquifer of Thiruvallur district, South India. Sustain Water Resour Manag 4:849-873. https://doi.org/10.1007/s40899-017-0180-x

Singh KP (1994) Temporal changes in the chemical quality of ground water in Ludhiana area. Curr Sci 66:375-378

Singh SK, Srivastava PK, Pandey AC, Gautam SK (2013) Integrated assessment of groundwater influenced by a confluence river system: concurrence with remote sensing and geochemical modelling. Water Resour Manage 27:4291-4313. https://doi.org/10. 1007/s11269-013-0408-y

Srinivasamoorthy K (2004) Hydrogeochemistry of groundwater in Salem District, Tamilnadu. Thesis, India

Srinivasamoorthy K, Nanthakumar C, Vasanthavigar M et al (2009) Groundwater quality assessment from a hard rock terrain, Salem district of Tamilnadu, India. Arab J Geosci 4:91-102. https://doi. org/10.1007/s12517-009-0076-7

Subba Rao N, Prakasa Rao J, John Devadas D, Srinivasa Rao KV, Krishna C, Nagamalleswara Rao B (2002) Hydrogeochemistry and groundwater quality in a developing urban environment of a semi-arid region, Guntur, Andhra Pradesh. J Geol Soc Ind 59:159-166

Sundaram R, Rao PS (1986) Lithostratigraphy of cretaceous and paleocene rocks of Trichinopoly District of Tamil Nadu, South India. Record Geolog Surv India 115:9-23

Tahaikt M, Ait Haddou A, El Habbani R et al (2008) Comparison of the performances of three commercial membranes in fluoride removal by nanofiltration. Contin Op Desalination 225:209-219. https:// doi.org/10.1016/j.desal.2007.07.007
Thilagavathi R, Chidambaram S, Prasanna MV et al (2012) A study on groundwater geochemistry and water quality in layered aquifers system of Pondicherry region, southeast India. Appl Water Sci 2:253-269. https://doi.org/10.1007/s13201-012-0045-2

Thilagavathi R, Chidambaram S, Thivya C et al (2016) Dissolved organic carbon in multilayered aquifers of Pondicherry Region (India): spatial and temporal variability and relationships to major ion chemistry. Nat Resour Res 26:119-135. https://doi.org/10. 1007/s11053-016-9306-3

Thilagavathi R, Chidambaram S, Thivya C, Prasanna MV, Keesari T, Pethaperumal S (2017) Assessment of groundwater chemistry in layered coastal aquifers using multivariate statistical analysis. Sustain Water Res Manage 3(1):55-69. https://doi.org/10.1007/ s40899-017-0078-7

Thivya C, Chidambaram S, Thilagavathi R et al (2013) Identification of the geochemical processes in groundwater by factor analysis in hard rock aquifers of Madurai District, South India. Arab J Geosci 7:3767-3777. https://doi.org/10.1007/s12517-013-1065-4

Thivya C, Chidambaram S, Rao MS et al (2015) Assessment of fluoride contaminations in groundwater of hard rock aquifers in Madurai district, Tamil Nadu (India). Appl Water Sci 7:1011-1023. https:// doi.org/10.1007/s13201-015-0312-0

Thivya C, Chidambaram S, Thilagavathi R et al (2018) Short-term periodic observation of the relationship of climate variables to groundwater quality along the KT boundary. J Clim Change 4:77-86. https://doi.org/10.3233/jcc-1800015

Vengosh A, Keren R (1996) Chemical modifications of groundwater contaminated by recharge of treated sewage effluent. J Contam Hydrol 23:347-360. https://doi.org/10.1016/0169-7722(96) 00019-8

WHO (2004) Guidelines for drinking water quality. World Health Organization, Geneva

Wilcox LV (1955) Classification and use of irrigation waters. U.S. Dept. of Agriculture, Washington, D.C.

Xu P, Feng W, Qian H, Zhang Q (2019a) Hydrogeochemical characterization and irrigation quality assessment of shallow groundwater in the Central-Western Guanzhong Basin, China. Int J Environ Res Public Health 16:1492. https://doi.org/10.3390/ijerph16091492

Xu P, Li M, Qian H et al (2019b) Hydrochemistry and geothermometry of geothermal water in the central Guanzhong Basin, China: a case study in Xi'an. Environ Earth Sci. https://doi.org/10.1007/ s12665-019-8099-1

Xu P, Zhang Q, Qian H et al (2019c) Characterization of geothermal water in the piedmont region of Qinling Mountains and LantianBahe Group in Guanzhong Basin, China. Environ Earth Sci. https://doi.org/10.1007/s12665-019-8418-6

Zhang Q, Xu P, Qian H (2019) Assessment of groundwater quality and human health risk (HHR) evaluation of nitrate in the CentralWestern Guanzhong Basin, China. Int J Environ Res Public Health 16:4246. https://doi.org/10.3390/ijerph16214246

Zhang Q, Xu P, Qian H (2020a) Groundwater quality assessment using improved water quality index (WQI) and human health risk (HHR) evaluation in a semi-arid Region of Northwest China. Expos Health 12:487-500. https://doi.org/10.1007/s12403-020-00345-w

Zhang Q, Xu P, Qian H, Yang F (2020b) Hydrogeochemistry and fluoride contamination in Jiaokou Irrigation District, Central China: assessment based on multivariate statistical approach and human health risk. Sci Total Environ 741:140460. https://doi.org/10. 1016/j.scitotenv.2020.140460

Publisher's Note Springer Nature remains neutral with regard to jurisdictional claims in published maps and institutional affiliations. 